\title{
THE HOMOSEXUAL LIFESTYLE: TIME USE IN SAME-SEX HOUSEHOLDS
}

\author{
Michael E. Martell \\ Bard College
}

LEANNE RONCOLATO

Franklin and Marshall College

\begin{abstract}
We are among the first to use American time-use data to investigate non-market behavior in gay and lesbian households. We contribute to a literature that has documented a gay disadvantage and lesbian advantage in the labor market. Many have proposed that this pattern reflects, relative to their heterosexual counterparts, higher levels of household labor among gay men and lower levels of household labor among lesbian women. Results show that gay men, parents in particular, spend more time in household production than heterosexual men. We find evidence of different time-use patterns for lesbians, but they are driven by characteristics not sexual orientation. These results also contribute to the economics of the household showing that time use in same-sex households with weaker gender constructs does not conform to the predictions of models that highlight comparative advantage as a source of specialization.
\end{abstract}

Keywords: Household Production, Sexual Orientation, Family Structure

\section{INTRODUCTION}

Gary Becker's model of the household motivated an expansive economic literature seeking to understand the internal workings of households as well as an extensive literature critiquing his work and proposing alternative models of the household [Becker (1981); McElroy and Horney (1981); Chiappori (1992); Sen (1990); Lundberg and Pollak (1994, 1996); Agarwal (1997); Carter and Katz (1997)]. Becker's approach, as well as the majority of household models which followed, implicitly assumes that households are comprised of a husband and a wife. These models, and the empirical work they have motivated, have greatly increased our understanding of heterosexual households; however, our understanding of samesex households and the applicability of traditional models therein remains limited.

\footnotetext{
We would like to thank Mary Hansen, Maria Floro, Alex Roomets, Kate Coventry, and participants at the 2015 International Association for Feminist Economics annual meeting for insightful feedback and comments that improved the manuscript. We would also like to thank the editor, Murat Iyigun, and two anonymous referees for helpful comments. Address correspondence to: Michael E. Martell, Department of Economics, Bard College, P.O. Box 5000, Annandale-on-Hudson, NY 12504; e-mail: mmartell@bard.edu.
} 
We investigate whether non-market time-use patterns vary with sexual orientation to make important contributions to the literature on the economic outcomes of gay men and lesbians and to the literature on the economics of the household.

First, we build on the literature that has produced an empirical puzzle: gay men earn less than heterosexual men, but lesbians generally earn more than heterosexual women. This puzzle has motivated a quickly growing literature aimed to explain the divergent labor market outcomes for lesbians and gay men. A popular explanation for these divergent patterns is varying household specialization patterns predicted by Becker's (1981) theory of the household [Jepsen (2007); Daneshvary et al. (2008, 2009); Antecol and Steinberger (2013)]. The specialization hypothesis argues that because there is still specialization according to gender in heterosexual households, lesbians will have comparatively lower unpaid household work burdens and thus greater market attachment than heterosexual women. Whereas, gay men will have comparatively higher unpaid household work burdens and thus lower labor market attachment than heterosexual men. The growing literature on this topic has focused on labor market outcomes of gays and lesbians and has documented their consistency with the specialization hypothesis. However, as we discuss below, outcomes consistent with specialization do not necessarily arise because of specialization or varying non-market time-use patterns. No work, to our knowledge, has directly investigated non-market household behavior to determine if time-use patterns systematically vary by sexual orientation. We are the first to directly empirically assess the validity of the household specialization explanation by investigating time spent on non-market activities in same-sex and different-sex households using American Time Use Survey (ATUS) data.

We use ATUS data from 2003 to 2013 [Ruggles et al. (2015)] and compare non-market time use in household labor, care labor, and leisure ${ }^{1}$ of cohabiting gay men and lesbians to their heterosexual counterparts. On average, gay men living with a partner spend more time in household labor than married heterosexual men, and lesbians living with a partner spend less time in household labor than heterosexual women. This difference in time use for gay men exists even after controlling for relevant characteristics. The greater amount of time spent in household labor is consistent with the specialization hypothesis. However, time use in lesbian households is not. After controlling for relevant characteristics, we find no statistically significant differences in time spent on household labor between lesbians and either married or unmarried cohabiting heterosexual women with one exception. Counter to the specialization hypothesis, we find unmarried cohabiting heterosexual women spend on average more time on household labor than lesbians. We do find differences in care labor between lesbians and heterosexual women in our baseline specification, but these results do not hold when partitioning the sample by parenthood or when considering only care labor done as a primary activity. The lack of a consistent difference between lesbians and heterosexual women is inconsistent with the specialization hypothesis as an explanation of labor market outcomes as well as the predictions in Becker's (1981) model of the household. 
Our second important contribution, which is to the literature on the economics of households, is our investigation into the behavior of members of same-sex households. We find little evidence of a "homosexual lifestyle". Differences in time use between gay and heterosexual men are driven by characteristics, in particular, the incidence of parenthood, not sexual orientation. We find little evidence of differences between lesbians and heterosexual women. While for all lesbians, we see differences in care labor, lesbians and married heterosexual women with children exhibit the same household time-use patterns. The primary differences we find between lesbians and cohabiting heterosexual women also appear driven by the experience of parenthood. While we find differences in care labor when comparing all lesbians to all married hetersexual women, we find no difference in care labor when we compare lesbians with children to heterosexual married women with children. The primary differences we find between lesbians and cohabiting heterosexual women also appear driven by the experience of parenthood.

These inter-household time-use findings contribute to the quickly growing literature on the economic experience of gay men and lesbians as well as provide a foundation for future work investigating the determinants of the intra-household division of labor within same-sex and different-sex households. In particular, these time-use patterns reveal the way in which gender continues to function as a key determinant of unpaid work in heterosexual and same-sex households. However, existing economic models of the household cannot readily explain the diverging mechanisms through which gender determines time use in gay, lesbian, and heterosexual households. As such, our findings provide a foundation on which future theoretical work can be developed to better understand the impact of gender on household decision-making in both heterosexual and same-sex households. Such research will be crucial to understanding households and the impact of public policies as same-sex households become more common and the social construction of gender evolves.

\section{LITERATURE REVIEW}

Time-use data provides valuable insights into household economics. A common and not surprising finding from studies of various countries is that women spend more time doing unpaid work and men spend more time doing paid work [Sayer (2005); Budlender (2000); Stratton (2015); Ruppanner and Maume (2016)]. ${ }^{2}$ This pattern helps explain the well-documented gender wage gap. However, little work has been done investigating time-use allocations within the households of samesex couples. As such, this paper makes important contributions to the literature on the economics of the household. Further, investigating the experiences of members of same-sex households builds on the quickly growing literature on the economic outcomes of gay men and lesbians.

The literature on the economic outcomes of gay men and lesbians has largely been in response to the perplexing findings of Badgett (1995). Badgett (1995) found a significant wage penalty for gay men and an insignificant wage differential 
for lesbians. The asymmetry in the earnings effect of sexual orientation by sex is difficult to reconcile with most, but not all, economic theories of discrimination. While inconsistent with most theories of discrimination based on a prejudice toward sexual orientation, the asymmetric earnings effects are consistent with varying levels of labor market engagement for gay men and lesbians. Lesbians are more likely than heterosexual women to have a partner who will share non-market work thus giving lesbians more time to spend on market work, perceptions of which could motivate employers to favor lesbians [Peplau and Fingerhut (2004)]. The same logic would predict higher levels of non-market work among cohabiting gay men.

The need to investigate patterns of household labor by sexual orientation is highlighted by the growing literature that has repeatedly documented a significant penalty for gay men and a significant premium for lesbians in the US [Berg and Lien (2002); Baumle and Poston (2011); Klawitter and Flatt (1998); CushingDaniels and Yeung (2009)], Sweden [Ahmed and Hammarstedt (2010); Ahmed et al. (2011, 2013)], the UK [Arabsheibani et al. (2004)], and the Netherlands [Plug and Berkhout (2008)]. ${ }^{3}$ Even though recent work suggests that these differentials are getting smaller for gay men [Cushing-Daniels and Yeung (2009); Clarke and Sevak (2013); Carpenter (2007)], this may be the result of the expansion of protection from discrimination for gay men and lesbians [Klawitter (2011); Martell (2013b, 2014)]. Explanations of varying patterns in household labor explaining the earnings effects of sexual orientation have risen in prominence [see, for example Black et al. (2007) and Daneshvary et al. (2009)], because evidence in favor of alternatives explanations has been inconclusive. ${ }^{4}$

There are several potential sources for differences in labor market attachment by sexual orientation. Varying labor market patterns may be the result of different amounts of time spent in the household due to (1) different budget constraints or labor/leisure trade-offs (2) different patterns in household specialization, or (3) different levels of aggregate household production [Black et al. (2007); Jepsen (2007); Clain and Leppel (2001); Berg and Lien (2002)]. Our paper investigates the broad hypothesis that differences in time spent in the household can explain differing labor market outcomes for gays and lesbians compared to their heterosexual counterparts. While differences in household time use between same-sex and different-sex households are generally explained as a product of household specialization [see, for example, Jepsen (2007) and Black et al. (2007)], it is important to note that such differences can occur without household specialization in same-sex households. Even if members of same-sex households do not specialize, time-use patterns will vary by sexual orientation due to the well-documented specialization by gender that occurs in different-sex households.

Existing empirical investigations into the household behavior of gay and lesbian couples have largely relied on indicators from the paid labor market to draw conclusions regarding the behavior of gays and lesbians within the household. To draw conclusions regarding specialization in gay and lesbian households, these investigations have tested if there are inequalities in labor market outcomes within 
gay and lesbian households. For example, the labor supply of members of samesex households are responsive to proxies typically associated with bargaining power such as differences in age and education (Orrefice, 2011). Cohabiting lesbians and gay men also exhibit intra-household inequalities in earnings, hours worked in paid labor, and the likelihood of working full-time suggesting that there is a primary worker and secondary worker even in same-sex households [Giddings et al. (2014); Jepsen and Jepsen (2015); Antecol et al. (2008)]. That these differences are less pronounced in same-sex households than in different sex households suggest that specialization is less pronounced in same-sex households, which authors argue could explain observed wage differentials [Jepsen and Jepsen (2015)]. Inequalities in labor market outcomes among household members may in part be explained by specialization if specialization allows some members of a household to be more attached to the labor market than others. ${ }^{5}$

Studies investigating labor market outcomes as proxies for household behavior are informative but incomplete in that they assume non-labor market behavior mirrors labor market behavior. Due to the possibility of differences in budget constraints, preferences and levels of household production, labor market patterns consistent with the household specialization hypothesis do not ensure that nonmarket time-use patterns will likewise be consistent. While an additional hour of paid labor can be offset by a decrease in an hour of unpaid labor indicating specialization, this is only one possible explanation. For example, lesbian women may spend more time on average working in the market than heterosexual women but may forgo leisure in order to spend an equal amount of time doing unpaid household and care labor due to preferences reflecting an internalization of gender norms. Furthermore, we may observe gay men on average spending less time on market work than heterosexual men, but this does not mean that gay men are necessarily spending more time on unpaid household work. There could be lower levels of household production in gay households. By looking directly at unpaid work and including an analysis of leisure, our approach offers a more precise investigation into the non-market behavior of gay men and lesbians and its relevance for market behavior and outcomes. We use time-use data to directly investigate the non-market behavior of cohabiting gay men and lesbians.

To our knowledge, Schneebaum (2013) is the only research that utilizes time-use data in the US to study the economics of gay and lesbian households. ${ }^{6}$ Schneebaum utilizes ATUS data to examine the responsiveness of time use to household characteristics of different-sex and same-sex couples. However, she does not test if patterns of non-market time use vary by sexual orientation after conditioning on observable characteristics. ${ }^{7}$ Schneebaum's descriptive statistics suggest that men in same-sex couples spend more time doing care work than men in different sex-couples and that women in same-sex couples also spend more time doing care work than women in different sex-couples (Schneebaum, 2013). ${ }^{8}$ It is important to note that gay men and lesbians must exhibit different patterns in time use, after controlling for relevant characteristics, for the specialization hypothesis to explain labor market outcomes. We build on Schneebaum by asking: are patterns 
of household labor, care labor, and leisure systematically different for gay men and lesbians than heterosexual men and women? Our results give limited support to the specialization hypothesis as an explanation of labor market outcomes for gay men. Evidence in support of the specialization hypothesis for gay men is driven by households with children. For lesbians evidence regarding care labor that supports the specialization hypothesis does not hold when partitioning the sample by parenthood or when narrowing the definition of care labor, because children are key determinants to the division of labor in all household types (Giddings et al., 2014). Furthermore, evidence contradicting the specialization hypothesis exist when considering women's time spent on household labor in all specifications.

By comparing time use of gays and lesbians to heterosexual men and women, we are able to build on the literature by testing the specialization hypothesis. However, differences in time use between individuals in same-sex and heterosexual households, do not necessarily reflect differences in patterns of household specialization within these households. Below, we discuss possible intra-household behavior which could explain the time-use patterns we find, but leave a full investigation into the processes that occur within same-sex households to future work.

\section{CONCEPTUAL FRAMEWORK}

Economic models of the household such as Becker's unitary household model, Chiaporri's collective model, as well as the group of cooperative, non-cooperative, and cooperative conflict bargaining models are most widely used to understand dynamics and outcomes of heterosexual households [Manser and Brown (1980); Becker (1981); McElroy and Horney (1981); Chiappori (1992); Sen (1990); Lundberg and Pollak (1994); Doss (1996); Lundberg and Pollak (1996); Agarwal (1997); Carter and Katz (1997)]..$^{9}$ One stylized fact that these models attempt to explain is heterosexual women's greater contribution to unpaid household and care labor relative to their heterosexual male partners. Becker's conclusions are based on the assumption of women's comparative advantage in care and household labor and men's comparative advantage in paid market labor. Chiapporri's collective model considers asymmetries in earnings potential and preferences as determinants of labor supply outcomes. Bargaining models focus on differences in fall back positions and threat points for men and women that arise due to labor market inequalities and institutions. While typically these models are used to understand dynamics within households, they can also be used to predict systematic differences between households, namely those with same-sex partners versus different-sex partners.

Given the current gender differences in labor market outcomes in the US, it seems reasonable to expect the earnings potential of two same-sex partners, controlling for other demographic characteristics, to be more similar than those of different-sex partners. While the channels through which earnings potential affects time use varies by household model, all else held constant, more equal earnings 
potential translates into either more equal time spent in household labor or a more equal likelihood of being the partner who specializes in unpaid household labor. ${ }^{10}$ Therefore, holding constant preferences, levels of household production, and budget constraints, existing economic models of the household predict that gay men will spend more time in the household and lesbians less time in the household relative to their heterosexual counterparts. The unequal division of labor stemming from the gender wage gap is particularly pronounced in different-sex households with children as the motherhood earnings penalty decreases earnings potential for women more than men. As such, the impact of parenthood, through its impact on earnings, should cause a more unequal distribution of household and care labor in different-sex households than same-sex households. It is important to note that the theoretical explanation for expected differences for individuals in same-sex versus heterosexual households is driven by inequality and social norms according to gender rather than sexual orientation. In the absence of such gender inequality in the labor market (and its effect on bargaining power), we would see equality in time use in different-sex and same-sex households. ${ }^{11}$ Systematic differences in time use by sexual orientation, then, result from widespread socio-economic gender inequalities.

Allowing for systematically different preferences in same-sex and heterosexual households can still yield a prediction consistent with the specialization hypothesis. Considering variation in preferences, it is possible that same-sex households (or individuals within same-sex households, depending on how utility maximization is modeled ${ }^{12}$ ) have stronger preferences for equality than different-sex households. ${ }^{13}$ If this is the case, holding the level of production constant, we would still expect on average lesbians to spend less time and gay men to spend more time on unpaid work than their heterosexual counterparts.

The predictions of existing household models become less clear when we allow for systematically different levels of household production in same-sex and different-sex households. Household activities and market activities are jointly determined, because income from market activities is a necessary input for household production. However, income from market activities can also be used to purchase market substitutes for household goods. Members of lesbian households, despite an observed earnings advantage relative to heterosexual women, still experience the large gender wage gap. This gender gap in earnings causes lesbian households to face stricter budget constraints than heterosexual households. With a stricter budget constraint, the possibility of purchasing market substitutes for household and care labor is limited. Therefore, it is possible that the impact of a stricter budget constraint on household time use could dominate the effect of a more equitable distribution of household duties causing lesbians to spend more time in household production. Even in the absence of different budget constraints, lesbian households may choose a different level of household production from heterosexual households if social institutions, such as intolerance and gender norms, make the purchasing of markets substitutes less enjoyable or less feasible. On the other hand, gay men may be more likely to purchase market substitutes for household 
labor or may choose to produce fewer household goods. A full understanding of differences in non-market time use must consider the possibility of such systematic differences in household production.

Finally, the differential impact of norms and institutions may lead to outcomes inconsistent with the specialization hypothesis. The role of institutions and specific gender norms have been theorized to impact the division of labor between two partners in a heterosexual household. ${ }^{14}$ Social norms, specifically those related to gender and family structure, can also explain systematic differences in time use and levels of household production in same-sex households compared to heterosexual households. Given the lack of sex-asymmetry within the household and unique challenges gay and lesbians face when constructing gender within a heteronormative society, the performance of gender is more difficult to predict in same-sex households. For example, both partners in a lesbian household may spend significant amounts of time on care labor attempting to meet societal expectations of motherhood. As such, the manifestation of gender in same-sex households may cause time use in same-sex households to be inconsistent with the specialization hypothesis. Another possibility is that pressures to emulate heteronormative conventions of the household may trump pressures to emulate traditional gender norms. For example, a gay man and a heterosexual man may have both been socialized as men, but pressures to create a heteronormative household may counteract pressure to conform to gender norms leading one gay partner to specialize in household and care labor. If this is the case, we would expect to find outcomes consistent with the specialization hypothesis for gay men.

\section{DATA}

We use data from the ATUS from 2003 to 2013. The ATUS is the only nation-wide time-use data source available for the US. The ATUS selects one member of a household from the Current Population Survey for inclusion in the survey. Survey respondents report the allocation of their time in minutes for one 24-hour period. ${ }^{15}$ Only selecting one member from each household limits the ability to investigate different patterns in time use within households. However, selecting one member of each household does allow us to investigate if time-use patterns vary by sexual orientation. Further, we leverage the range of economic and demographic characteristics to investigate patterns of time use within households by investigating the impact of characteristics such as earnings that theoretically determine the intrahousehold distribution of time use. As we are interested in investigating patterns of time use as they relate to household specialization and labor market attachment, we are primarily interested in studying individuals who are of prime working age. Therefore, like Blau and Kahn (2005) and Martell (2014), we limit our sample to respondents who are between the age of 25 years and 54 years to focus on workers who are likely to exhibit a higher degree of labor market attachment and a higher incidence of family obligations such as childcare. This restriction also allows us 
to focus on workers who are less likely to be choosing full-time education or retirement. $^{16}$

Gay men and lesbians may be identified in the survey if they cohabit with a member of the same sex. ${ }^{17}$ As such, our analysis excludes single individuals. Our sample includes 102 cohabiting gay men, 16,539 married heterosexual men, 1,008 cohabiting unmarried heterosexual men, 136 cohabiting lesbians, 18,844 married heterosexual women, and 1,105 cohabiting unmarried heterosexual women. While small, the sample size of gay men and lesbians is larger than or comparable to the sample sizes used in many analyses of gay and lesbian labor market outcomes utilizing GSS data [see Badgett (1995); Martell (2013a); Berg and Lien (2002)].

Descriptive statistics are shown in Tables 1 and 2. For the most part, the characteristics of cohabiting gay men and lesbians are consistent with existing demographic research [see Black et al. (2007)]. Cohabiting gay men are more likely to live in an urban area, more likely to be white, are on average older, ${ }^{18}$ more educated and have less children than married heterosexual men and cohabiting heterosexual men. Because gay men have higher levels of observable human capital such as education, descriptive statistics show a small but insignificant difference in earnings between cohabiting gay and married heterosexual men. The small difference here is consistent with research showing that the gay earnings penalty has been shrinking [Cushing-Daniels and Yeung (2009)] as well as research showing that the observed gay earnings penalty is mitigated by higher levels of human capital [Martell (2013a)]. The earnings of the partners of gay men are higher than earnings of the partners of heterosexual men, which is not surprising given the gender wage gap. Total household earnings are similar for each type of household. In our sample, gay men are on average older, earn more and are more likely to own a home than cohabiting heterosexual men.

The lesbians in our sample are more likely to live in urban areas, are on average younger, more educated, have higher earnings, and have fewer children than married heterosexual women. The earnings of partners of lesbians are found to be lower than those of the partners of married heterosexual women and household earnings are more equitable. While lesbians are less likely to own a home than married heterosexual women, lesbians are more likely to own their home than cohabiting heterosexual women. Consistent with existing analyses of the geography of same-sex households [Gates and Cooke (2011)], lesbians are more likely than gay men as well as cohabiting and married heterosexual women to live in a state in which same sex marriage is legal. This residential pattern highlights the importance of controlling for not only regional variations in the residences of same-sex households but also variations in the legal institutions in which same-sex and different-sex households reside as we discuss below. ${ }^{19}$ We do not find a similar significant difference when comparing cohabiting gay men to heterosexual men.

With the ATUS data, we investigate daily minutes spent in household labor, leisure, and care labor on the day of data collection. These time categories are as defined in the ATUS classifications. ${ }^{20}$ Consistent with standard practices in time-use research, ${ }^{21}$ we define total care labor as including all care labor reported 
TABLE 1. Descriptive statistics for demographic variables

Gay/lesbian Married heterosexual Cohabiting heterosexual

\begin{tabular}{|c|c|c|c|}
\hline \multicolumn{4}{|l|}{ Men } \\
\hline White & 0.9313725 & 0.8657298 & 0.8005952 \\
\hline Non-hispanic & 0.8627451 & 0.8571515 & 0.8412698 \\
\hline Urban residence & 0.9607843 & $0.8393259^{* * *}$ & $0.8105159^{* * *}$ \\
\hline Summer & 0.245098 & 0.2432317 & 0.2331349 \\
\hline Third adult present & 0.0588235 & $0.1571455^{* *}$ & 0.1061508 \\
\hline Week-end & 0.5294118 & 0.5092778 & 0.4980159 \\
\hline Child under 6 years & 0.0588235 & $0.383525^{* * *}$ & $0.2519841^{\text {*** }}$ \\
\hline Child 6 years to 18 years & 0.0980392 & $0.5595912^{* * *}$ & $0.2519841^{* * *}$ \\
\hline Home owner & 0.7941176 & 0.8194926 & $0.5039683^{* * *}$ \\
\hline Same-sex marriage legal & 0.0784314 & 0.0674697 & 0.0684524 \\
\hline Age & 41.56863 & 40.634 & $36.42361^{* * *}$ \\
\hline Years education & 15.35294 & $14.28576^{* * *}$ & $13.14583^{* * *}$ \\
\hline Weekly earnings & 1022.116 & 1087.123 & $701.3696^{* * *}$ \\
\hline Spouse's earnings & 1050.98 & $532.7611^{* * *}$ & $466.5703^{* * *}$ \\
\hline Earnings share & 0.5092486 & $0.6753539^{* * *}$ & $0.5995174^{* *}$ \\
\hline Number of children & 0.254902 & $1.524427^{* * *}$ & $0.9365079^{* * *}$ \\
\hline Observations & 102 & 16437 & 1008 \\
\hline \multicolumn{4}{|l|}{ Women } \\
\hline White & 0.875 & 0.8600616 & 0.8262443 \\
\hline Non-hispanic & 0.8897059 & 0.854118 & 0.8461538 \\
\hline Urban residence & 0.9117647 & $0.8361813^{*}$ & $0.8352941^{*}$ \\
\hline Summer & 0.2720588 & 0.2449055 & 0.2533937 \\
\hline Third adult present & 0.0441176 & $0.1672681^{* * *}$ & $0.1085973^{*}$ \\
\hline Week-end & 0.5661765 & 0.5061027 & 0.5022624 \\
\hline Child under 6 years & 0.1323529 & $0.3610698^{* * *}$ & $0.2687783^{* * *}$ \\
\hline Child 6 years to 18 years & 0.2352941 & $0.56044^{* * *}$ & $0.325792^{*}$ \\
\hline Home owner & 0.7058824 & $0.8297601^{* * *}$ & $0.5402715^{\text {*** }}$ \\
\hline Same-sex marriage legal & 0.1544118 & $0.0668117^{* * *}$ & $0.0941176^{*}$ \\
\hline Age & 39.75735 & 39.70611 & $35.68688^{* * *}$ \\
\hline Years education & 15.66912 & $14.36919^{* * *}$ & $13.56652^{* * *}$ \\
\hline Weekly earnings & 893.6821 & $551.1404^{* * *}$ & $522.321^{* * *}$ \\
\hline Spouse's earnings & 844.8976 & $1040.736^{* *}$ & $692.6815^{* *}$ \\
\hline Earnings share & 0.5045756 & $0.3319973^{* * *}$ & $0.4278388^{* *}$ \\
\hline Number of children & 0.625 & $1.493738^{* * *}$ & $1.033484^{* * *}$ \\
\hline Observations & 136 & 18844 & 1105 \\
\hline
\end{tabular}

Note: Authors' calculations from American Time Use Survey data, 2003-2013. * Difference from gay/lesbian average significant at $10 \%^{* *}$ Difference significant at $5 \%{ }^{* * *}$ Difference significant at $1 \%$.

as a primary activity and childcare reported as a secondary activity. Secondary childcare is defined as time when at least one child under the age of 13 years is in the respondent's care and at least one child is awake. It is particularly important to include secondary childcare as a component of care labor given our interest in time use and its relationship to labor market attachment. Even though it is 
TABLE 2. Descriptive statistics for daily time use in minutes

\section{All men}

All women

Gay Married heterosexual Cohabiting heterosexual Lesbian Married heterosexual Cohabiting heterosexual

\begin{tabular}{|c|c|c|c|c|c|c|}
\hline Household labor & 126 & $96^{*}$ & $92^{*}$ & 118 & $159^{* *}$ & 136 \\
\hline Care labor & 57 & $276^{* * *}$ & $180^{* * *}$ & 183 & $372^{* * *}$ & $248^{*}$ \\
\hline Secondary childcare & 36 & $221^{* * *}$ & $143^{* * *}$ & 139 & $283^{* *}$ & $192^{*}$ \\
\hline Leisure & 259 & 242 & 274 & 215 & 219 & 244 \\
\hline Observations & 102 & $\begin{array}{r}16437 \\
\mathbf{M e}\end{array}$ & 1,008 & 136 & $\begin{array}{l}18,844 \\
\text { Womeı }\end{array}$ & 1,105 \\
\hline
\end{tabular}

Gay Married heterosexual Cohabiting heterosexual Lesbian Married heterosexual Cohabiting heterosexual

Household labor

$\begin{array}{ll}194 & 96 \\ 375 & 351\end{array}$

$\begin{array}{lll}\text { Care labor } & 375 & 351 \\ \text { Secondary childcare } & 264 & 284\end{array}$

$6^{* *} \quad 97^{*}$

$351 \quad 344$

$284 \quad 280$

Leisure $\quad 190 \quad 232$

Observations

$14 \quad 12,771$

515

271
515

Men without children

\begin{tabular}{ccc}
132 & 164 & 146 \\
443 & 483 & 430 \\
344 & 372 & 340 \\
208 & 206 & 235 \\
55 & 14,342 & 624 \\
\multicolumn{3}{c}{ Women without children }
\end{tabular}

Gay Married heterosexual Cohabiting heterosexual Lesbian Married heterosexual Cohabiting heterosexual

Household labor

11598

Care labor

$7 \quad 13$

Secondary childcare

Leisure

13

Observations

0
270

0

278

278
3,666

88
10
0
278
493

109
6
0
220
81

$144^{*}$

122

00

$258 \quad 256$

Note: Authors' calculations from American Time Use Survey data, 2003-2013. ${ }^{*}$ Difference from gay/lesbian average significant at $10 \%{ }^{* *}$ Difference significant at $5 \%$ ${ }^{* * *}$ Difference significant at $1 \%$. 
possible to complete household labor or leisure activity while a child is present, it is much more difficult to do paid market work while a child is in one's care. This difficulty is most pronounced when paid market work is outside the household as is generally the case in the US. ${ }^{22}$

Table 2 highlights the importance of considering the varying incidence of parenthood across household types in understanding time use in same-sex households. Gay men do considerably more household labor but less care labor than both married and cohabiting heterosexual men. While the difference in household labor is as expected given the traditional gender division of labor for heterosexual men, the difference in care labor is not. For married and cohabiting heterosexual men, about $80 \%$ of total care labor is secondary childcare and for gay men $63 \%$ of care labor is secondary childcare. When we partition the sample into men with children and men without children, the difference in time spent on care labor disappears. The difference in the amount of time gay and heterosexual men spend on household labor persists in the subsample of men with children. For the subsample without children, we see no statistically significant difference in average time spent on household and care labor. The differences in time spent in leisure are not statistically significant in the full sample or either subsample.

Without any controls, it appears that cohabiting lesbians exhibit different patterns of time spent in household labor and care labor than their heterosexual counterparts, as shown in Table 2 . Cohabiting lesbians spend approximately 40 minutes less time in household labor and 90 fewer minutes in care labor than married heterosexual women. Relative to cohabiting heterosexual women, lesbians spend nearly 60 minutes less time in care labor but time spent in household labor and leisure are similar. Once again the differences in time spent in household labor are as expected for lesbians. The difference in care labor is as well. Similar to men, a large portion of total care labor is secondary childcare. Further, a higher share of lesbian women have small children than gay men, but they are still less likely than heterosexual women to have children. When the sample is partitioned into women with and without children, the differences in average daily time use between lesbians and heterosexual women become statistically insignificant. The one exception is that heterosexual married women without children spend a statistically significant greater amount of time on household labor than lesbians without children. The varying patterns of parenthood highlight the importance of controlling for children when investigating time-use data. We explore the impact of parenthood below and are among the first to incorporate the presence of children in comparing the time use of cohabiting gay men and lesbians to their heterosexual counterparts. ${ }^{23}$

\section{EMPIRICAL SPECIFICATION}

To estimate daily time use in household labor, leisure, and care labor, we follow the approaches of Kimmel and Connelly (2007), while incorporating controls also included in Giddings et al. (2014) and Jepsen and Jepsen (2015). We are interested 
in estimating average time-use patterns across household types. Since reports of no time spent in any of these categories represent classical measurement error and not censoring, we model time use via seemingly unrelated OLS regressions (Stewart, 2013). ${ }^{24}$ Because the use of survey weights have the potential to lead to imprecise estimates in the context of predicting time use for same-sex households, we do not use the ATUS survey weights (Solon et al., 2015). ${ }^{25}$ Specifically, we estimate

$$
\hat{y}_{i}=\alpha+\beta_{1} H_{i}+\beta_{2} T_{i}+\boldsymbol{\beta} X_{i}+\epsilon_{i},
$$

where $y_{i}=$ household labor, care labor, and leisure for individual $i . H_{i}$ is an indicator for cohabiting with a partner of the same-sex and is the key explanatory variable, $T_{i}$ is a vector of year indicators, and $X_{i}$ includes relevant demographic characteristics: age and its square, weekly earnings, spouse's weekly earnings, the percent of household income that is comprised of the respondents earnings, years of education, and indicators for: being white, an urban residence, home ownership, the presence of a child under 6 years, the presence of children between 6 years and 18 years, the presence of non-own child, the presence of third adult, a summer time diary, a weekend time diary, a holiday time diary. We also include an indicator for respondents living in a state where same-sex marriage is legal to control for varying levels of tolerance of homosexuality as well as geographic variation in time use. The same-sex marriage indicator is used in place of regional controls as same-sex marriage legalization is regionally clustered. ${ }^{26}$ In some specifications discussed below, we interact the same-sex indicator with the presence of children to investigate any differences in the impact of parenthood on time use by sexual orientation.

We control for the weekly earnings of the respondent as well as those of the respondent's partner as earnings potential affects time use in and outside of the household. However, as labor market outcomes such as earnings are in part the product of the intra-household distribution of labor, there are theoretical reasons for suspecting that weekly earnings may be endogenous. This potential endogeneity poses an empirical difficulty for researchers interested in estimating the impact of wages on household time use. To correct for this potential endogeneity, researchers can use predicted wages or instrumental variables to predict the exogenous effect of earnings on time use. Unfortunately, our data lack valid instruments for earnings as well as the ideal covariates necessary to make accurate earnings predictions. As such, we follow Bredtmann (2014) and use actual earnings in estimation. A priori, the extent to which the household process that determines weekly earnings varies by sexual orientation, and would bias our estimates, is unclear. Therefore, we do not believe its endogeneity will bias the estimate of our variable of interest: the member of a same-sex household indicator. Even though Hersch and Stratton (1997) find the results of instrumental variables estimates to be nearly identical to the standard OLS estimates of wages on time 
work suggesting that earnings endogeneity does not bias time-use estimates, we still caution readers in interpreting the coefficient estimate of earnings in isolation.

In addition to earnings, we also control for the percent of household income that is comprised of the individual's earnings. The share of household income comprised of the respondents earnings or some measure of relative wages is a commonly used proxy for household bargaining power [see, for examples, Kimmel and Connoly (2007), Masterson (2012), and Hener (2015)]. Even though it is an imperfect proxy for bargaining power, controlling for the respondent's earnings share allows us to test for differences in time use correcting for the distribution of relative earnings potential (the opportunity costs of time) of household members as well as the ability of household members to exert influence over the intrahousehold distribution of household time use. Both of these factors may vary by sexual orientation.

In testing, if time use varies by sexual orientation, it is unclear whether married or unmarried cohabiting heterosexuals is the most appropriate reference group for cohabiting gay men and lesbians a priori. Unfortunately, marital status of same-sex couples is not observable throughout the entire span of our data. At the beginning of our data, no states allowed gay men and lesbians to legally marry [Movement Advancement Project (2014)]. Throughout the time span of the data, in many states, gay men and lesbians were in marriage-like relationships but not allowed to marry. On the other hand, some of the cohabiting gay men and lesbians may be more akin to cohabiting heterosexuals. After conducting log likelihood ratio test comparing specifications that combine cohabiting and married respondents to specifications that partition the sample, we conclude that it is most appropriate to estimate time use separately allowing coefficient estimates to vary reflecting different time use and bargaining processes across household types. ${ }^{27}$

Investigating the impact of parenthood on time use among same-sex households is difficult, and children are an important determinant of time use and household specialization. Our descriptive statistics show that same-sex household are less likely to have children. If selection into parenthood varies by sexual orientation, which we discuss in detail below, conditioning on the presence of children may bias our estimates. To mediate this potential bias and examine the impact of parenthood on time use, we investigate differences in time use separately by the presence of children instead of simply conditioning on children as primarily done in the existing literature.

\section{RESULTS}

\subsection{Men}

As expected, cohabiting gay men spend more time in household labor than married heterosexual men. Table 3 shows that gay men spend on average 24 more minutes per day doing household labor than married heterosexual men. This finding is not surprising. The household bargaining literature has produced the stylized 
TABLE 3. Time-use estimates for gay and heterosexual men

\begin{tabular}{|c|c|c|c|c|c|c|}
\hline & \multicolumn{3}{|c|}{ Cohabiting gay vs. married men } & \multicolumn{3}{|c|}{ Cohabiting gay vs. unmarried men } \\
\hline & Household labor & Care labor & Leisure & Household labor & Care labor & Leisure \\
\hline Gay & $\begin{array}{c}24.285^{*} \\
(12.727)\end{array}$ & $\begin{array}{c}-79.624^{* * *} \\
(24.672)\end{array}$ & $\begin{array}{c}1.474 \\
(16.767)\end{array}$ & $\begin{array}{c}19.384 \\
(14.305)\end{array}$ & $\begin{array}{l}-3.613 \\
(23.594)\end{array}$ & $\begin{array}{c}13.810 \\
(21.655)\end{array}$ \\
\hline Age & $\begin{array}{c}1.369 \\
(1.443)\end{array}$ & $\begin{array}{l}27.340^{* * *} \\
(2.797)\end{array}$ & $\begin{array}{c}-0.011 \\
(1.901)\end{array}$ & $\begin{array}{c}2.900 \\
(4.669)\end{array}$ & $\begin{array}{c}2.141 \\
(7.701)\end{array}$ & $\begin{array}{r}-10.038 \\
(7.068)\end{array}$ \\
\hline Age squared & $\begin{array}{r}-0.002 \\
(0.018)\end{array}$ & $\begin{array}{c}-0.377^{* * *} \\
(0.034)\end{array}$ & $\begin{array}{c}0.006 \\
(0.023)\end{array}$ & $\begin{array}{r}-0.024 \\
(0.060)\end{array}$ & $\begin{array}{c}-0.043 \\
(0.100)\end{array}$ & $\begin{array}{c}0.143 \\
(0.091)\end{array}$ \\
\hline White & $\begin{array}{l}19.470^{* * *} \\
(2.961)\end{array}$ & $\begin{array}{l}10.681^{*} \\
(5.740)\end{array}$ & $\begin{array}{c}-10.968^{* * *} \\
(3.901)\end{array}$ & $\begin{array}{c}14.172 \\
(9.855)\end{array}$ & $\begin{array}{l}-0.624 \\
(16.255)\end{array}$ & $\begin{array}{c}-54.570^{* * * *} \\
(14.919)\end{array}$ \\
\hline Urban residence & $\begin{array}{c}-5.836^{* *} \\
(2.755)\end{array}$ & $\begin{array}{r}-3.007 \\
(5.340)\end{array}$ & $\begin{array}{c}1.327 \\
(3.629)\end{array}$ & $\begin{array}{r}-19.586^{*} \\
(10.174)\end{array}$ & $\begin{array}{c}1.493 \\
(16.781)\end{array}$ & $\begin{array}{c}4.656 \\
(15.402)\end{array}$ \\
\hline Years education & $\begin{array}{c}0.408 \\
(0.375)\end{array}$ & $\begin{array}{l}7.261^{* * *} \\
(0.727)\end{array}$ & $\begin{array}{c}-3.411^{* * *} \\
(0.494)\end{array}$ & $\begin{array}{r}-0.327 \\
(1.568)\end{array}$ & $\begin{array}{c}1.342 \\
(2.586)\end{array}$ & $\begin{array}{r}-4.320^{*} \\
(2.373)\end{array}$ \\
\hline Earnings share & $\begin{array}{c}-57.964^{* * *} \\
(5.988)\end{array}$ & $\begin{array}{c}-94.863^{* * *} \\
(11.608)\end{array}$ & $\begin{array}{c}-112.116^{* * *} \\
(7.889)\end{array}$ & $\begin{array}{r}-33.952 \\
(20.659)\end{array}$ & $\begin{array}{c}-108.916^{* * *} \\
(34.074)\end{array}$ & $\begin{aligned}- & 100.361^{* * *} \\
& (31.274)\end{aligned}$ \\
\hline Child under 6 years & $\begin{array}{c}1.989 \\
(2.425)\end{array}$ & $\begin{array}{c}227.575^{* * *} \\
(4.701)\end{array}$ & $\begin{array}{c}-27.854^{* * *} \\
(3.195)\end{array}$ & $\begin{array}{c}4.398 \\
(9.727)\end{array}$ & $\begin{array}{l}323.441^{* * *} \\
(16.043)\end{array}$ & $\begin{array}{r}-26.277^{*} \\
(14.724)\end{array}$ \\
\hline Child between 6 years and 18 years & $\begin{array}{l}6.730^{* * * *} \\
(2.246)\end{array}$ & $\begin{array}{c}149.500^{* * * *} \\
(4.354)\end{array}$ & $\begin{array}{c}-18.973^{* * *} \\
(2.959)\end{array}$ & $\begin{array}{c}8.952 \\
(9.582)\end{array}$ & $\begin{array}{l}188.363^{* * *} \\
(15.805)\end{array}$ & $\begin{array}{c}14.778 \\
(14.506)\end{array}$ \\
\hline Non-own child present & $\begin{array}{c}5.248 \\
(8.276)\end{array}$ & $\begin{array}{l}140.898^{* * *} \\
(16.043)\end{array}$ & $\begin{array}{l}-8.505 \\
(10.902)\end{array}$ & $\begin{array}{l}-0.911 \\
(13.299)\end{array}$ & $\begin{array}{l}203.814^{* * *} \\
(21.936)\end{array}$ & $\begin{array}{r}-14.591 \\
(20.133)\end{array}$ \\
\hline Year effects & Yes & Yes & Yes & Yes & Yes & Yes \\
\hline Observations & 16,539 & & & 1,110 & & \\
\hline$R^{2}$ & 0.0850 & 0.382 & 0.168 & 0.104 & 0.470 & 0.156 \\
\hline$C h i^{2}$ & 1535.6 & 10223.2 & 3349.2 & 128.5 & 983.1 & 205.0 \\
\hline$p$ & 0.00 & 0.00 & 0.00 & 0.00 & 0.00 & 0.00 \\
\hline
\end{tabular}

Note: Authors' calculations from Seemingly Unrelated Regressions on American Time Use Survey data, 2003-2013. Specifications also include controls for weekly earnings, weekly earnings of spouse/partner, as well as indicators for time use on a holiday, time use during the summer, the presence of a non-own child, home ownership, residence in a state with same-sex marriage legal. ${ }^{*}$ Significant at $10 \%{ }^{* *}$ Significant at $5 \%{ }^{* * *}$ Significant at $1 \%$. 
fact that women tend to specialize in household production while heterosexual men specialize in the labor market and spend less time on household and care work. However, this result is not found when comparing gay men to cohabiting heterosexual men. Counter to expectations of the specialization hypothesis, we see that gay men spend on average about 80 minutes less per day on care labor than married heterosexual men. ${ }^{28}$ We see no statistically significant difference in care labor between unmarried cohabiting heterosexual men and gay men. The signs and significance of control variables are as expected: the presence of other adults reduces time spent in care labor; increases in education are associated with a decrease in leisure, weekends, and holidays are associated with more non-market time use; the presence of children under 6 years increases care labor by more than 3 hours. $^{29}$

We investigate the impact of parenthood to assess the source of time-use differences estimated in Table 3. Table 3 controls for the presence of children but does not correct for any selection into parenthood or any differential impact of parenthood across sexual orientations. However, there are several reasons to believe that selection into parenthood may differ by sexual orientation. First, unplanned pregnancies should be much less frequent for gay men and lesbians. ${ }^{30}$ Second, the marginal cost of planned parenthood is higher for cohabiting gay men and lesbians than it is for heterosexuals regardless of the path to parenthood chosen given the increased financial and institutional costs same-sex couples experience. Even though these differences in the marginal cost of parenthood comprise a small portion of the total cost of parenthood, and may not lead to meaningful differences in the desire for children by sexual orientation, these differences may affect the experience of and path into parenthood for same-sex households. Lacking a valid and equally consistent instrument for parenthood, we estimate time use separately for households with children under 18 years and households without children. Investigating the impact of parenthood, regardless of selection, allows us to investigate the source of the time-use differences estimated in Table 3. Since the differences estimated above include households with and without children, we should find larger time-use differences for gay men when we compare time use in households with children given the role children play in determining household specialization in heterosexual households. For robustness, we also interact the presence of small children with the same-sex household indicator to capture any difference in the experience of or the path into parenthood, and resulting differences in needs and characteristics of children, in same-sex households.

Consistent with theories predicting specialization by gender to increase with children, Table 4 shows that the difference in household labor for gay men is larger in households with children. Cohabiting gay men perform approximately 95 minutes more household labor per day than both cohabiting and married heterosexual men in households with children. The greater amount of household labor of gay parents relative to heterosexual men highlights the importance of controlling for children in comparing time-use patterns. The significant difference in household labor among gay parents as estimated in Table 4 suggests that the unconditional 
TABLE 4. Time-use estimates for gay and heterosexual men with children

\begin{tabular}{|c|c|c|c|c|c|c|}
\hline & \multicolumn{3}{|c|}{ Cohabiting gay vs. married men } & \multicolumn{3}{|c|}{ Cohabiting gay vs. unmarried men } \\
\hline & Household labor & Care labor & Leisure & Household labor & Care labor & Leisure \\
\hline Gay & $\begin{array}{l}95.814^{* * *} \\
(33.734)\end{array}$ & $\begin{array}{c}72.338 \\
(70.558)\end{array}$ & $\begin{array}{r}-12.094 \\
(43.683)\end{array}$ & $\begin{array}{l}95.457^{* *} \\
(37.860)\end{array}$ & $\begin{array}{l}112.819 \\
(84.440)\end{array}$ & $\begin{array}{l}-4.545 \\
(56.467)\end{array}$ \\
\hline Age & $\begin{array}{c}1.550 \\
(1.673)\end{array}$ & $\begin{array}{l}35.047^{* * *} \\
(3.499)\end{array}$ & $\begin{array}{r}-1.406 \\
(2.166)\end{array}$ & $\begin{array}{c}-5.433 \\
(7.579)\end{array}$ & $\begin{array}{c}12.763 \\
(16.903)\end{array}$ & $\begin{array}{l}-1.029 \\
(11.303)\end{array}$ \\
\hline Age squared & $\begin{array}{c}-0.005 \\
(0.021)\end{array}$ & $\begin{array}{c}-0.488^{* * *} \\
(0.044)\end{array}$ & $\begin{array}{c}0.019 \\
(0.027)\end{array}$ & $\begin{array}{c}0.081 \\
(0.100)\end{array}$ & $\begin{array}{c}-0.202 \\
(0.222)\end{array}$ & $\begin{array}{c}0.032 \\
(0.149)\end{array}$ \\
\hline White & $\begin{array}{l}17.638^{* * *} \\
(3.395)\end{array}$ & $\begin{array}{c}7.735 \\
(7.101)\end{array}$ & $\begin{array}{c}-8.730^{* *} \\
(4.396)\end{array}$ & $\begin{array}{r}-12.219 \\
(13.933)\end{array}$ & $\begin{array}{c}3.696 \\
(31.075)\end{array}$ & $\begin{array}{c}-74.936^{* * *} \\
(20.780)\end{array}$ \\
\hline Urban residence & $\begin{array}{r}-5.133^{*} \\
(3.117)\end{array}$ & $\begin{array}{c}3.429 \\
(6.520)\end{array}$ & $\begin{array}{c}-1.665 \\
(4.037)\end{array}$ & $\begin{array}{c}-28.826^{* *} \\
(13.030)\end{array}$ & $\begin{array}{c}21.487 \\
(29.061)\end{array}$ & $\begin{array}{c}5.750 \\
(19.434)\end{array}$ \\
\hline Years education & $\begin{array}{c}0.581 \\
(0.422)\end{array}$ & $\begin{array}{l}8.653^{* * *} \\
(0.883)\end{array}$ & $\begin{array}{c}-3.343^{* * *} \\
(0.546)\end{array}$ & $\begin{array}{c}1.587 \\
(2.332)\end{array}$ & $\begin{array}{c}5.378 \\
(5.202)\end{array}$ & $\begin{array}{r}-6.092^{*} \\
(3.479)\end{array}$ \\
\hline Earnings share & $\begin{array}{c}-59.753^{* * *} \\
(6.814)\end{array}$ & $\begin{array}{c}-126.128^{* * *} \\
(14.253)\end{array}$ & $\begin{array}{c}-96.152^{* * *} \\
(8.824)\end{array}$ & $\begin{array}{r}-56.570^{*} \\
(30.692)\end{array}$ & $\begin{array}{c}-167.289^{* *} \\
(68.453)\end{array}$ & $\begin{array}{r}-81.021^{*} \\
(45.776)\end{array}$ \\
\hline Child under 6 years & $\begin{array}{r}-2.306 \\
(2.703)\end{array}$ & $\begin{array}{c}104.195^{* * *} \\
(5.653)\end{array}$ & $\begin{array}{c}-17.615^{* * *} \\
(3.500)\end{array}$ & $\begin{array}{l}-0.823 \\
(11.801)\end{array}$ & $\begin{array}{l}169.675^{* * *} \\
(26.319)\end{array}$ & $\begin{array}{r}-17.024 \\
(17.600)\end{array}$ \\
\hline Year effects & Yes & Yes & Yes & Yes & Yes & Yes \\
\hline Observations & 12,785 & & & 529 & & \\
\hline$R^{2}$ & 0.0871 & 0.261 & 0.162 & 0.125 & 0.215 & 0.172 \\
\hline$C h i^{2}$ & 1219.4 & 4524.8 & 28371.5 & 420.0 & 982.4 & 109.8 \\
\hline$p$ & 0.00 & 0.00 & 0.00 & 0.00 & 0.00 & 0.00 \\
\hline
\end{tabular}

Note: Authors' calculations from Seemingly Unrelated Regressions on American Time Use Survey data, 2003-2013. Specifications also include controls for weekly earnings, weekly earnings of spouse/partner, as well as indicators for time use on a holiday, time use during the summer, the presence of a non-own child, home ownership, residence in a state with same-sex marriage legal. ${ }^{*}$ Significant at $10 \%{ }^{* *}$ Significant at $5 \%{ }^{* * *}$ Significant at $1 \%$. 
averages discussed in Table 1 of the descriptive statistics are driven by differences in characteristics: the likelihood of parenthood. Once we control for demographic characteristics, we find that, as expected, gay men with children spend more time on household labor than heterosexual men with children. It may seem curious that the differences are in household labor rather than care labor. The presence of children however does not only increase the amount of care labor but also the amount of household labor, i.e. cleaning, cooking, and laundry. While gay and heterosexual men seem to do similar levels of care labor, gay men in our sample take on a greater amount of the increased household labor generated from the presence of children than heterosexual men.

To investigate the source of the greater difference in household labor among households with children, we investigate the impact of the presence of children under 6 years. We allow the impact of the presence of a child under 6 years to vary by sexual orientation, results of which are available in appendix Table A.1. ${ }^{31}$ Including the interaction term, although producing a statistically insignificant coefficient estimate, eliminates the overall difference in household labor between gay men and both married and unmarried cohabiting heterosexual men. The interaction term is statistically insignificant in all regressions with the exception of care labor. Cohabiting gay men with children under six appear to do 141 minutes more care labor per day than heterosexual married men with a child under 6 years. Thus, differences in unpaid time-use patterns between gay men and heterosexual men appear to be driven by the greater amount of time gay men spend with their young children.

Finally, we investigate the source of the overall difference in time use for gay men by comparing time use in households without children. If differences in time use between gay and heterosexual men are explained by the persistence of specialization according to gender in heterosexual households, we expect differences in time use between gay and heterosexual men to be smaller, but still significant and meaningful, among households without children. We confirm that overall differences in unpaid time use are driven by the impact of young children on cohabiting gay men by showing that time-use differences are smaller for cohabiting gay men without children in Table 5. Consistent with specialization according to gender as a source of time-use patterns, the differences in household labor are much less pronounced. However, the lack of a statistically significant and meaningfully large time-use difference in households without children is inconsistent with the specialization hypothesis, which predicts that all gay men, not just gay parents, will exhibit time-use differences.

\subsection{Women}

As shown in Table 6, the only statistically significant differences between the time-use patterns of lesbians and cohabiting heterosexual women or married heterosexual women are in care labor. Consistent with the specialization hypothesis, we see that lesbians spend on average 45 less minutes per day on care labor than 
TABLE 5. Time-use estimates for men without children

\begin{tabular}{|c|c|c|c|c|c|c|}
\hline & \multicolumn{3}{|c|}{ Cohabiting gay vs. married men } & \multicolumn{3}{|c|}{ Cohabiting gay vs. unmarried men } \\
\hline & Household labor & Care labor & Leisure & Household labor & Care labor & Leisure \\
\hline \multirow[t]{2}{*}{ Gay } & 10.518 & -4.597 & -1.310 & 3.648 & -1.816 & 18.847 \\
\hline & $(14.271)$ & $(6.017)$ & $(19.726)$ & $(15.543)$ & $(5.208)$ & $(23.963)$ \\
\hline \multirow[t]{2}{*}{ Age } & 2.838 & $-3.026^{* *}$ & 3.852 & 8.082 & 1.752 & -13.409 \\
\hline & $(2.791)$ & $(1.177)$ & $(3.857)$ & (5.909) & $(1.980)$ & (9.111) \\
\hline \multirow[t]{2}{*}{ Age squared } & -0.018 & $0.038^{* * *}$ & -0.037 & -0.089 & -0.024 & 0.190 \\
\hline & $(0.034)$ & $(0.014)$ & $(0.047)$ & $(0.076)$ & $(0.025)$ & (0.117) \\
\hline \multirow[t]{2}{*}{ White } & $25.453^{* * *}$ & $4.905^{*}$ & $-17.202^{* *}$ & $34.301^{* *}$ & $-9.765^{* *}$ & -34.715 \\
\hline & $(6.098)$ & $(2.571)$ & $(8.429)$ & $(13.860)$ & $(4.644)$ & $(21.368)$ \\
\hline \multirow[t]{2}{*}{ Urban residence } & -7.982 & $-4.240^{*}$ & 11.704 & -3.394 & $-14.007^{* *}$ & 2.667 \\
\hline & (5.919) & (2.496) & (8.181) & (16.264) & $(5.450)$ & $(25.075)$ \\
\hline \multirow[t]{2}{*}{ Years education } & -0.324 & 0.012 & $-2.902^{* *}$ & -2.409 & -0.632 & -3.559 \\
\hline & $(0.840)$ & $(0.354)$ & (1.161) & (2.128) & (0.713) & (3.280) \\
\hline \multirow[t]{2}{*}{ Earnings share } & $-53.556^{* * *}$ & -1.777 & $-157.755^{\text {*** }}$ & -21.859 & 5.928 & $-109.072^{* *}$ \\
\hline & $(12.857)$ & $(5.421)$ & (17.771) & (29.870) & (10.009) & (46.051) \\
\hline Year effects & Yes & Yes & Yes & Yes & Yes & Yes \\
\hline Observations & 3,754 & & & 581 & & \\
\hline$R^{2}$ & 0.0839 & 0.0239 & 0.157 & 0.127 & 0.0655 & 0.174 \\
\hline$C h i^{2}$ & 343.9 & 91.93 & 697.6 & 84.82 & 40.71 & 122.7 \\
\hline$p$ & 0.00 & 0.00 & 0.00 & 0.00 & 0.02 & 0.00 \\
\hline
\end{tabular}

Note: Authors' calculations from Seemingly Unrelated Regressions on American Time Use Survey data, 2003-2013. Specifications also include controls for weekly earnings, weekly earnings of spouse/partner, as well as indicators for time use on a holiday, time use during the summer, home ownership, residence in a state with same-sex marriage legal. ${ }^{*}$ Significant at $10 \%{ }^{* *}$ Significant at $5 \%{ }^{* * *}$ Significant at $1 \%$. 
TABLE 6. Time-use estimates for lesbian and heterosexual women

\begin{tabular}{|c|c|c|c|c|c|c|}
\hline & \multicolumn{3}{|c|}{ Cohabiting lesbian vs. married women } & \multicolumn{3}{|c|}{ Cohabiting lesbian vs. unmarried women } \\
\hline & Household labor & Care labor & Leisure & Household labor & Care labor & Leisure \\
\hline Lesbian & $\begin{array}{r}-14.628 \\
(11.982)\end{array}$ & $\begin{array}{c}-45.982^{* *} \\
(21.314)\end{array}$ & $\begin{array}{c}-13.368 \\
(13.054)\end{array}$ & $\begin{array}{c}-20.257 \\
(12.814)\end{array}$ & $\begin{array}{c}35.105^{*} \\
(20.502)\end{array}$ & $\begin{array}{r}-24.782 \\
(15.375)\end{array}$ \\
\hline Age & $\begin{array}{l}5.044^{* * *} \\
(1.438)\end{array}$ & $\begin{array}{l}28.558^{* * *} \\
(2.559)\end{array}$ & $\begin{array}{c}-5.657^{* * *} \\
(1.567)\end{array}$ & $\begin{array}{c}7.235 \\
(4.680)\end{array}$ & $\begin{array}{c}0.702 \\
(7.487)\end{array}$ & $\begin{array}{c}10.697^{*} \\
(5.615)\end{array}$ \\
\hline Age squared & $\begin{array}{c}-0.037^{* *} \\
(0.018)\end{array}$ & $\begin{array}{c}-0.428^{* * *} \\
(0.032)\end{array}$ & $\begin{array}{l}0.075^{* * *} \\
(0.020)\end{array}$ & $\begin{array}{c}-0.064 \\
(0.061)\end{array}$ & $\begin{array}{c}-0.019 \\
(0.097)\end{array}$ & $\begin{array}{r}-0.129^{*} \\
(0.073)\end{array}$ \\
\hline White & $\begin{array}{l}16.336^{* * *} \\
(2.937)\end{array}$ & $\begin{array}{l}13.230^{* *} \\
(5.225)\end{array}$ & $\begin{array}{c}-0.752 \\
(3.200)\end{array}$ & $\begin{array}{l}33.114^{* * *} \\
(10.287)\end{array}$ & $\begin{array}{l}32.829^{* *} \\
(16.458)\end{array}$ & $\begin{array}{c}6.413 \\
(12.342)\end{array}$ \\
\hline Urban residence & $\begin{array}{c}-0.509 \\
(2.773)\end{array}$ & $\begin{array}{l}11.599^{* *} \\
(4.933)\end{array}$ & $\begin{array}{c}-1.068 \\
(3.021)\end{array}$ & $\begin{array}{l}-7.010 \\
(10.735)\end{array}$ & $\begin{array}{c}5.390 \\
(17.175)\end{array}$ & $\begin{array}{c}20.286 \\
(12.880)\end{array}$ \\
\hline Years education & $\begin{array}{c}-2.599^{* * *} \\
(0.395)\end{array}$ & $\begin{array}{l}6.397^{* * *} \\
(0.703)\end{array}$ & $\begin{array}{c}-1.732^{* * *} \\
(0.430)\end{array}$ & $\begin{array}{c}-0.313 \\
(1.660)\end{array}$ & $\begin{array}{r}-2.623 \\
(2.655)\end{array}$ & $\begin{array}{c}0.445 \\
(1.991)\end{array}$ \\
\hline Earnings share & $\begin{array}{c}-82.991^{* * *} \\
(6.091)\end{array}$ & $\begin{array}{c}-190.116^{* * *} \\
(10.834)\end{array}$ & $\begin{array}{c}-89.656^{* * *} \\
(6.636)\end{array}$ & $\begin{array}{c}-74.026^{* * *} \\
(20.038)\end{array}$ & $\begin{array}{c}-172.107^{* * *} \\
(32.059)\end{array}$ & $\begin{array}{c}-63.965^{* * *} \\
(24.042)\end{array}$ \\
\hline Child under 6 years & $\begin{array}{l}14.883^{* * *} \\
(2.594)\end{array}$ & $\begin{array}{c}318.274^{* * *} \\
(4.613)\end{array}$ & $\begin{array}{c}-47.705^{* * *} \\
(2.826)\end{array}$ & $\begin{array}{c}7.214 \\
(9.835)\end{array}$ & $\begin{array}{l}398.182^{* * *} \\
(15.736)\end{array}$ & $\begin{array}{c}-48.965^{* * *} \\
(11.801)\end{array}$ \\
\hline Child between 6 years and 18 years & $\begin{array}{l}22.743^{* * *} \\
(2.321)\end{array}$ & $\begin{array}{c}179.799^{* * *} \\
(4.128)\end{array}$ & $\begin{array}{c}-22.643^{* * *} \\
(2.528)\end{array}$ & $\begin{array}{l}22.145^{* *} \\
(9.148)\end{array}$ & $\begin{array}{l}215.928^{* * *} \\
(14.636)\end{array}$ & $\begin{array}{c}-24.803^{* *} \\
(10.976)\end{array}$ \\
\hline Non-own child present & $\begin{array}{c}9.182 \\
(8.146)\end{array}$ & $\begin{array}{l}231.571^{* * *} \\
(14.490)\end{array}$ & $\begin{array}{r}-7.137 \\
(8.875)\end{array}$ & $\begin{array}{c}9.332 \\
(15.143)\end{array}$ & $\begin{array}{l}226.613^{* * *} \\
(24.227)\end{array}$ & $\begin{array}{r}-13.332 \\
(18.169)\end{array}$ \\
\hline Year effects & Yes & Yes & Yes & Yes & Yes & Yes \\
\hline Observations & 18,980 & & & 1241 & & \\
\hline$R^{2}$ & 0.0746 & 0.516 & 0.133 & 0.0970 & 0.575 & 0.148 \\
\hline$C h i^{2}$ & 1530.6 & 20272.0 & 2899.6 & 133.3 & 1681.5 & 215.6 \\
\hline$p$ & 0.00 & 0.00 & 0.00 & 0.00 & 0.00 & 0.00 \\
\hline
\end{tabular}

Note: Authors' calculations from Seemingly Unrelated Regressions on American Time Use Survey data, 200-2013. Specifications also include controls for weekly earnings, weekly earnings of spouse/partner, as well as indicators for time use on a holiday, time use during the summer, the presence of a non-own child, home ownership, residence in a state with same-sex marriage legal. ${ }^{*}$ Significant at $10 \%{ }^{* *}$ Significant at 5\% ${ }^{* * *}$ Significant at $1 \%$. 
heterosexual married women. However, counter to the specialization hypothesis, we see that lesbians do on average 35 more minutes of care labor compared to unmarried heterosexual women. When considering care labor done only as a primary activity, the differences in time use between lesbians and heterosexual women, both married and unmarried cohabiting, disappear. ${ }^{32}$ Also, inconsistent with the specialization hypothesis, we see no statistically significant differences in household labor between cohabiting lesbians and heterosexual women, either married or unmarried. ${ }^{33}$ The lack of a difference in time spent on household labor between lesbian and heterosexual women once we control for relevant characteristics suggests that the differences in aggregate time-use patterns shown in Table 2 arise from differences in characteristics between lesbian and heterosexual women. We do note that the signs and significance of the control variables are consistent with expectations. ${ }^{34}$ As in the previous section, we continue by investigating differential impacts of parenthood for lesbians.

As discussed above, persistent household specialization according to gender in heterosexual households should lead to more pronounced time-use differences among households with children. To investigate the impact of parenthood and patterns of specialization, we estimate time use separately for households with children under 18 years and households without children. Contrary to the predictions of the specialization hypothesis, we find that, in households with children, cohabiting lesbians spend more time in childcare than unmarried heterosexual but not married heterosexual women. Table 7 shows that cohabiting lesbians with children spend 86 more minutes per day doing care labor than cohabiting unmarried heterosexual women. As such, the overall difference in time spent in care labor arises from the lower incidence of parenthood in lesbian households, not systematic differences in the relative distribution of care labor in same-sex and heterosexual households. This is inconsistent with the specialization hypothesis.

As in the previous section, we interact the presence of children under 6 years with the lesbian indicator variable to allow the impact of small children to vary between cohabiting lesbians and heterosexual women. These results are available in appendix Table A.2. We find further evidence against the hypothesis that the overall results reflect patterns of household specialization. Unlike our findings for men, the time use of cohabiting lesbians does not respond differently to the presence of small children than the time use of heterosexual women. There is no significantly different time-use pattern between cohabiting lesbians and married heterosexual women. The difference between cohabiting lesbians and cohabiting heterosexual women in time spent in childcare is estimated to be larger at 114 minutes per day. The lack of a difference in time-use patterns for lesbian and married heterosexual women is inconsistent with our expectations from the wage differential literature. However, the smaller amount of time that lesbians spend in household labor relative to unmarried cohabiting heterosexual women is consistent with the lesbian wage advantage being larger relative to unmarried heterosexual women than married heterosexual women [Jepsen (2007)]. 
TABLE 7. Time-use estimates for lesbian and heterosexual women with children

\begin{tabular}{|c|c|c|c|c|c|c|}
\hline & \multicolumn{3}{|c|}{ Cohabiting lesbian vs. married women } & \multicolumn{3}{|c|}{ Cohabiting lesbian vs. unmarried women } \\
\hline & Household labor & Care labor & Leisure & Household labor & Care labor & Leisure \\
\hline \multirow[t]{2}{*}{ Lesbian } & -18.004 & 11.253 & 4.217 & -12.771 & $86.359^{* *}$ & -21.970 \\
\hline & $(18.577)$ & $(35.359)$ & $(19.640)$ & $(20.933)$ & $(39.723)$ & $(22.880)$ \\
\hline \multirow[t]{2}{*}{ Age } & $6.185^{* * *}$ & $39.356^{* * *}$ & $-7.534^{* * *}$ & $13.119^{*}$ & -3.591 & 4.586 \\
\hline & $(1.711)$ & $(3.257)$ & $(1.809)$ & $(7.412)$ & $(14.065)$ & $(8.101)$ \\
\hline \multirow[t]{2}{*}{ Age squared } & $-0.043^{* *}$ & $-0.596^{* * *}$ & $0.093^{* * *}$ & -0.140 & 0.033 & -0.044 \\
\hline & $(0.022)$ & $(0.041)$ & $(0.023)$ & $(0.099)$ & $(0.188)$ & $(0.108)$ \\
\hline \multirow[t]{2}{*}{ White } & $10.286^{* * *}$ & 8.294 & 2.844 & $42.461^{* * *}$ & 41.793 & -11.704 \\
\hline & $(3.426)$ & $(6.521)$ & $(3.622)$ & $(15.358)$ & $(29.143)$ & $(16.786)$ \\
\hline \multirow[t]{2}{*}{ Urban residence } & -2.682 & $19.784^{* * *}$ & -2.399 & -7.164 & 20.021 & $34.220^{* *}$ \\
\hline & $(3.217)$ & $(6.124)$ & $(3.401)$ & (14.299) & $(27.134)$ & $(15.628)$ \\
\hline \multirow[t]{2}{*}{ Years education } & $-3.212^{* * *}$ & $6.994^{* * *}$ & $-1.470^{* * *}$ & -1.148 & -3.083 & 0.304 \\
\hline & $(0.447)$ & $(0.852)$ & $(0.473)$ & $(2.406)$ & $(4.566)$ & (2.630) \\
\hline \multirow[t]{2}{*}{ Earnings share } & $-94.406^{* * *}$ & $-251.850^{* * *}$ & $-73.329^{* * *}$ & $-82.301^{* * *}$ & $-228.512^{* * *}$ & -48.154 \\
\hline & (7.114) & (13.540) & $(7.521)$ & $(27.781)$ & $(52.717)$ & $(30.364)$ \\
\hline \multirow[t]{2}{*}{ Child under 6 years } & $7.399^{* *}$ & $160.192^{* * *}$ & $-34.109^{* * *}$ & -3.466 & $211.529^{* * *}$ & $-33.717^{* *}$ \\
\hline & $(2.900)$ & $(5.519)$ & (3.066) & $(12.552)$ & $(23.818)$ & (13.719) \\
\hline Year effects & Yes & Yes & Yes & Yes & Yes & Yes \\
\hline Observations & 14,397 & & & 679 & & \\
\hline$R^{2}$ & 0.0725 & 0.315 & 0.114 & 0.0946 & 0.301 & 0.152 \\
\hline$C h i^{2}$ & 21593.6 & 6634.7 & 30945.3 & 802.6 & 2084.8 & 1693.6 \\
\hline$p$ & 0.00 & 0.00 & 0.00 & 0.00 & 0.00 & 0.00 \\
\hline
\end{tabular}

Note: Authors' calculations from Seemingly Unrelated Regressions on American Time Use Survey data, 2003-2013. Specifications also include controls for weekly earnings, weekly earnings of spouse/partner, as well as indicators for time use on a holiday, time use during the summer, the presence of a non-own child, home ownership, residence in a state with same-sex marriage legal. ${ }^{*}$ Significant at $10 \%^{* *}$ Significant at $5 \%{ }^{* * *}$ Significant at $1 \%$. 
Finally, we investigate the source of the overall differences in time use by estimating differences in time use for households without children. Compared to households with children, time-use differences for lesbians should be smaller in households without children, since parenthood is a key determinant in theories of household specialization. In households without children, cohabiting lesbians spend approximately one half hour less on household labor than cohabiting heterosexual women as shown in Table 8. That the difference in time use is larger in households without children is again inconsistent with theories that predict children increase specialization according to gender, even though this difference is consistent with the literature documenting a wage advantage for lesbians.

Taken altogether, there is very little support of the specialization hypothesis for lesbians. The specialization hypothesis predicts that all lesbians (not just lesbians without children) should spend less time in the household than heterosexual women. To the contrary, lesbian parents spend more time in household labor than cohabiting heterosexual women as is shown in Table 7. The lack of a difference between time use between lesbians and married heterosexual women is striking, since the differences between gay men are most pronounced relative to married heterosexual men. While both lesbians and married heterosexual women appear to be performing the gender roles prescribed to women, cohabiting heterosexual women with children do not. Perhaps cohabiting heterosexual women with children who have violated social norms regarding having children outside of marriage are also more likely to violate social norms regarding the performance of gender as it pertains to household time use. Cohabiting heterosexual women with children may furthermore be less willing to fulfill their gender role due to a potentially lower level of commitment existing in unmarried households. A lower level of commitment, and higher level of independence of women in unmarried households, may motivate women to be less willing to invest in unpaid household labor due to its impact on labor market attachment. On the other hand, unmarried cohabiting heterosexual women without children, who have not yet challenged the social norm of having children before marriage, may still be trying to convince their partner to commit to marriage. One way in which they may be trying to do this is by taking on a higher share of unpaid household labor.

\section{DISCUSSION AND CONCLUSION}

This paper provides insight into two key investigations. The first is whether time spent on non-market activities may explain the observed labor market advantage of lesbians relative to heterosexual women and disadvantage of gay men relative to heterosexual men. Our results provide conflicting evidence of varying household time-use patterns between lesbians and heterosexual women as an explanation of labor market outcomes. Unconditional averages suggest that lesbians may have more favorable labor market outcomes than heterosexual women, because they are spending less time on non-market work. However, the finding of a wage premium for lesbians in the labor market is shown to hold even after controlling for 
TABLE 8. Time-use estimates for lesbian and heterosexual women without children

\begin{tabular}{|c|c|c|c|c|c|c|}
\hline & \multicolumn{3}{|c|}{ Cohabiting lesbian vs. married women } & \multicolumn{3}{|c|}{ Cohabiting lesbian vs. unmarried women } \\
\hline & Household labor & Care labor & Leisure & Household labor & Care labor & Leisure \\
\hline Lesbian & $\begin{array}{r}-17.885 \\
(15.989)\end{array}$ & $\begin{array}{r}-4.987 \\
(7.620)\end{array}$ & $\begin{array}{r}-30.062 \\
(18.704)\end{array}$ & $\begin{array}{c}-31.419^{* *} \\
(15.537)\end{array}$ & $\begin{array}{r}-5.684 \\
(5.202)\end{array}$ & $\begin{array}{r}-33.672 \\
(20.884)\end{array}$ \\
\hline Age & $\begin{array}{c}5.412^{* *} \\
(2.736)\end{array}$ & $\begin{array}{c}-2.706^{* *} \\
(1.304)\end{array}$ & $\begin{array}{c}1.620 \\
(3.200)\end{array}$ & $\begin{array}{c}3.243 \\
(5.884)\end{array}$ & $\begin{array}{r}-1.600 \\
(1.970)\end{array}$ & $\begin{array}{l}15.726^{* *} \\
(7.909)\end{array}$ \\
\hline Age squared & $\begin{array}{r}-0.048 \\
(0.033)\end{array}$ & $\begin{array}{l}0.040^{* *} \\
(0.016)\end{array}$ & $\begin{array}{r}-0.014 \\
(0.039)\end{array}$ & $\begin{array}{r}-0.011 \\
(0.076)\end{array}$ & $\begin{array}{c}0.026 \\
(0.025)\end{array}$ & $\begin{array}{r}-0.198^{*} \\
(0.102)\end{array}$ \\
\hline White & $\begin{array}{l}30.022^{* * *} \\
(5.731)\end{array}$ & $\begin{array}{c}2.600 \\
(2.731)\end{array}$ & $\begin{array}{r}-6.015 \\
(6.704)\end{array}$ & $\begin{array}{c}26.140^{*} \\
(13.580)\end{array}$ & $\begin{array}{r}-1.836 \\
(4.547)\end{array}$ & $\begin{array}{c}29.597 \\
(18.253)\end{array}$ \\
\hline Urban residence & $\begin{array}{c}1.062 \\
(5.525)\end{array}$ & $\begin{array}{r}-3.903 \\
(2.633)\end{array}$ & $\begin{array}{c}6.124 \\
(6.463)\end{array}$ & $\begin{array}{l}-5.493 \\
(16.283)\end{array}$ & $\begin{array}{c}1.724 \\
(5.452)\end{array}$ & $\begin{array}{r}-15.224 \\
(21.886)\end{array}$ \\
\hline Years education & $\begin{array}{c}-2.272^{* * *} \\
(0.866)\end{array}$ & $\begin{array}{c}0.175 \\
(0.413)\end{array}$ & $\begin{array}{c}-1.431 \\
(1.013)\end{array}$ & $\begin{array}{c}1.193 \\
(2.277)\end{array}$ & $\begin{array}{c}0.364 \\
(0.762)\end{array}$ & $\begin{array}{r}-0.624 \\
(3.060)\end{array}$ \\
\hline Earnings share & $\begin{array}{c}-50.645^{* * *} \\
(12.250)\end{array}$ & $\begin{array}{c}-19.909^{* * *} \\
(5.838)\end{array}$ & $\begin{array}{c}-142.926^{* * *} \\
(14.330)\end{array}$ & $\begin{array}{r}-53.304^{*} \\
(28.720)\end{array}$ & $\begin{array}{r}-8.307 \\
(9.616)\end{array}$ & $\begin{array}{r}-87.146^{* *} \\
(38.603)\end{array}$ \\
\hline Year effects & Yes & Yes & Yes & Yes & Yes & Yes \\
\hline Observations & 4,583 & & & 562 & & \\
\hline$R^{2}$ & 0.0817 & 0.0233 & 0.133 & 0.124 & 0.0652 & 0.182 \\
\hline$C h i^{2}$ & 407.6 & 109.4 & 704.2 & 79.24 & 39.22 & 124.8 \\
\hline$p$ & 0.00 & 0.00 & 0.00 & 0.00 & 0.04 & 0.00 \\
\hline
\end{tabular}

Note: Authors' calculations from Seemingly Unrelated Regressions on American Time Use Survey data, 2003-2013. Specifications also include controls for weekly earnings, weekly earnings of spouse/partner, as well as indicators for time use on a holiday, time use during the summer, home ownership, residence in a state with same-sex marriage legal. ${ }^{*}$ Significant at $10 \%{ }^{* *}$ Significant at $5 \%{ }^{* * *}$ Significant at $1 \%$. 
demographic characteristics. Contrary to the findings on labor market outcomes, we do not find robust differences in non-market time use between lesbians and married women after controlling for demographic characteristics. We find very few differences between lesbians and cohabiting heterosexual women. Where we do find differences, the differences are counter to the theory of specialization: lesbians with children spend more time in household and care labor than cohabiting heterosexual women. We find support of the specialization hypothesis only in that lesbians without children spend less on time on household labor than cohabiting heterosexual women without children. Overall, our analysis indicates that observed unconditional differences in time spent on household labor, leisure, and care labor are due to the fact that lesbians are less likely to have children which affects their aggregate time-use patterns. Differences in lesbians' observed time use compared to married or cohabiting heterosexual women appear to be driven by characteristics not sexual orientation.

Our results regarding time-use patterns for men is likewise complicated but does provide some support for the specialization hypothesis. For the full sample, our results for household labor are consistent but results for care labor are inconsistent with the specialization hypothesis. Given the differential selection into parenthood, our preferred specifications are those which partition the sample into parents and non-parents. Gay men with children spend approximately an hour and half more time per day in household labor than married heterosexual men. Differences in care labor and leisure are not found when the sample is partitioned by parenthood. These results suggest that differences in time spent on household labor between cohabiting gay and heterosexual men may be part of the explanation behind the less favorable labor market outcomes of gay men relative to heterosexual men. The larger amount of time gay men are spending doing unpaid work provides them with less time available for paid market work compared to heterosexual men. However, the lack of a difference in the time-use patterns of gay or heterosexual households without children is inconsistent with the labor market disadvantage gay men experience.

The finding that gay parents spend more time on household labor than heterosexual male parents suggests gay men are more willing to adopt roles outside their gender prescription. The fact that no difference in household labor is found between heterosexual and gay men without children leads to the question: Who is doing the housework in gay households? One possibility is that gay men are more likely to purchase household services or market substitutes for household services, such as prepared meals. ${ }^{35}$ It is also possible that there are positive returns to a more egalitarian distribution of household labor in gay households or different preferences or requirements for the amount of household production required in gay households compared to heterosexual households.

Through investigating the source of asymmetric labor market outcomes for gay men and lesbians, we also make a key contribution to the literature on the economics of households. Finding minimal differences (only relative to cohabiting women) in non-market time between lesbians and heterosexual women suggests 
that on average, more time is being spent on unpaid household and care labor in lesbian households than heterosexual households. One hypothesis is that lesbians may be "preforming their gender" and fulfilling expectations of what it is to be a woman, despite the fact that they also have partners who are taking on "women's responsibilities". Our results suggest that the socialization of women to be caregivers continues to influence behavior even when they are members of households whose composition does not conform to a conventional heterosexual structure. This issue is investigated in more depth within sociological work, i.e. Oerton (1998), Dalton and Bielby (2000), and Padavic and Butterfield (2011), which examine the complications of gender, sexuality, and identity in lesbian households with qualitative research.

Given that we only have data for one partner in any specific household, our investigation into the division of labor within particular households is limited. Nevertheless, our results show that time-use differences by sexual orientation are driven by characteristics, namely parenthood, rather than a "homosexual lifestyle". Future work should further test specialization within gay and lesbian households, investigating the differences in the ways in which gay men and lesbians emulate or reject traditional heterosexual household structures and the extent to which individuals continue to "perform" their gender regardless of sexual orientation. This line of research gives us information not only about same-sex households, but furthermore provides insights into the power that gender still has in heterosexual households as a determinant of the division of labor.

While it is clear that selection into parenthood is different for same-sex couples than it is for heterosexual couples, our results also indicate that the experience of gay and lesbian parenthood is unique. Future work should investigate the impact of public policy on selection into parenthood and how changing household demographics affects the incidence and experiences of same-sex parenthood. Understanding the formation and impact of public policy on same-sex households will further our understanding of how same-sex households function. It will also inform future efforts to develop more complete economic models of the household, which are critical for designing effective public policies to promote the well-being of all types of workers and families. The need for these models and policies will only continue to grow as unconventional households become more conventional. 


\section{APPENDIX A}

TABLE A.1. Time-use estimates for men with children interacting presence of young children with sexual orientation

\begin{tabular}{|c|c|c|c|c|c|c|}
\hline & \multicolumn{3}{|c|}{ Cohabiting gay vs. married men } & \multicolumn{3}{|c|}{ Cohabiting gay vs. unmarried men } \\
\hline & Household labor & Care labor & Leisure & Household labor & Care labor & Leisure \\
\hline \multirow[t]{2}{*}{ Gay } & 59.853 & -32.784 & -34.348 & 63.119 & 29.126 & -40.638 \\
\hline & $(44.593)$ & $(93.266)$ & $(57.748)$ & $(47.422)$ & $(105.721)$ & $(70.765)$ \\
\hline \multirow[t]{2}{*}{ Age } & 1.528 & $34.985^{* * *}$ & -1.420 & -6.012 & 11.265 & -1.675 \\
\hline & (1.673) & $(3.498)$ & (2.166) & (7.587) & $(16.914)$ & $(11.322)$ \\
\hline \multirow[t]{2}{*}{ Age squared } & -0.005 & $-0.487^{* * *}$ & 0.019 & 0.089 & -0.182 & 0.041 \\
\hline & $(0.021)$ & $(0.044)$ & $(0.027)$ & $(0.100)$ & $(0.223)$ & $(0.149)$ \\
\hline \multirow[t]{2}{*}{ White } & $17.621^{* * *}$ & 7.685 & $-8.740^{* *}$ & -12.492 & 2.988 & $-75.241^{* * *}$ \\
\hline & $(3.395)$ & (7.100) & $(4.396)$ & $(13.918)$ & $(31.029)$ & (20.769) \\
\hline \multirow[t]{2}{*}{ Urban residence } & -5.067 & 3.621 & -1.624 & $-27.837^{* *}$ & 24.048 & 6.854 \\
\hline & (3.118) & $(6.520)$ & $(4.037)$ & $(13.044)$ & $(29.079)$ & $(19.464)$ \\
\hline \multirow[t]{2}{*}{ Years education } & 0.589 & $8.674^{* * *}$ & $-3.339^{* * *}$ & 1.730 & 5.747 & $-5.933^{*}$ \\
\hline & $(0.422)$ & $(0.883)$ & $(0.546)$ & (2.333) & $(5.201)$ & (3.482) \\
\hline \multirow[t]{2}{*}{ Earnings share } & $-59.798^{* * *}$ & $-126.260^{* * *}$ & $-96.180^{* * *}$ & $-57.760^{*}$ & $-170.368^{* *}$ & $-82.349^{*}$ \\
\hline & $(6.814)$ & $(14.251)$ & $(8.824)$ & (30.673) & $(68.382)$ & $(45.772)$ \\
\hline \multirow[t]{2}{*}{ Child under 6 years } & -2.415 & $103.874^{* * *}$ & $-17.682^{* * *}$ & -2.911 & $164.272^{* * *}$ & -19.354 \\
\hline & (2.704) & $(5.655)$ & $(3.502)$ & $(11.930)$ & $(26.598)$ & (17.803) \\
\hline \multirow[t]{2}{*}{ Gay* children under 6 years } & 83.925 & $245.336^{*}$ & 51.937 & 77.672 & 201.018 & 86.690 \\
\hline & $(68.070)$ & $(142.367)$ & $(88.150)$ & $(68.731)$ & $(153.227)$ & $(102.564)$ \\
\hline Year effects & Yes & Yes & Yes & Yes & Yes & Yes \\
\hline Observations & 12,785 & & & 529 & & \\
\hline$R^{2}$ & 0.0872 & 0.262 & 0.162 & 0.127 & 0.218 & 0.173 \\
\hline$C h i^{2}$ & 8651.5 & 4528.8 & 2473.0 & 77.28 & 987.3 & 1252.9 \\
\hline$p$ & 0.00 & 0.00 & 0.00 & 0.00 & 0.00 & 0.00 \\
\hline
\end{tabular}

Note: Authors' calculations from Seemingly Unrelated Regressions on American Time Use Survey data, 2003-2013. Specifications also include controls for weekly earnings, weekly earnings of spouse/partner, as well as indicators for time use on a holiday, time use during the summer, the presence of a non-own child, home ownership, residence in a state with same-sex marriage legal. ${ }^{*}$ Significant at $10 \%{ }^{* *}$ Significant at $5 \%{ }^{* * *}$ Significant at $1 \%$. 
TABLE A.2. Time-use estimates for women with children interacting presence of young children with sexual orientation

\begin{tabular}{|c|c|c|c|c|c|c|}
\hline & \multicolumn{3}{|c|}{ Cohabiting lesbian vs. married women } & \multicolumn{3}{|c|}{ Cohabiting lesbian vs. unmarried women } \\
\hline & Household labor & Care labor & Leisure & Household labor & Care labor & Leisure \\
\hline Lesbian & $\begin{array}{c}-17.054 \\
(22.649)\end{array}$ & $\begin{array}{c}45.411 \\
(43.107)\end{array}$ & $\begin{array}{c}4.557 \\
(23.946)\end{array}$ & $\begin{array}{r}-10.949 \\
(25.237)\end{array}$ & $\begin{array}{l}114.158^{* *} \\
(47.853)\end{array}$ & $\begin{array}{r}-31.775 \\
(27.576)\end{array}$ \\
\hline Age & $\begin{array}{l}6.187^{* * *} \\
(1.711)\end{array}$ & $\begin{array}{l}39.411^{* * *} \\
(3.257)\end{array}$ & $\begin{array}{c}-7.534^{* * *} \\
(1.809)\end{array}$ & $\begin{array}{l}13.229^{*} \\
(7.461)\end{array}$ & $\begin{array}{l}-1.907 \\
(14.147)\end{array}$ & $\begin{array}{c}3.992 \\
(8.152)\end{array}$ \\
\hline Age squared & $\begin{array}{c}-0.043^{* *} \\
(0.022)\end{array}$ & $\begin{array}{c}-0.597^{* * *} \\
(0.041)\end{array}$ & $\begin{array}{l}0.093^{* * *} \\
(0.023)\end{array}$ & $\begin{array}{c}-0.141 \\
(0.100)\end{array}$ & $\begin{array}{c}0.010 \\
(0.189)\end{array}$ & $\begin{array}{r}-0.036 \\
(0.109)\end{array}$ \\
\hline White & $\begin{array}{l}10.288^{* * *} \\
(3.426)\end{array}$ & $\begin{array}{c}8.371 \\
(6.521)\end{array}$ & $\begin{array}{c}2.845 \\
(3.622)\end{array}$ & $\begin{array}{l}42.547^{* * *} \\
(15.372)\end{array}$ & $\begin{array}{l}43.106 \\
(29.147)\end{array}$ & $\begin{array}{r}-12.167 \\
(16.797)\end{array}$ \\
\hline Urban residence & $\begin{array}{c}-2.687 \\
(3.218)\end{array}$ & $\begin{array}{l}19.626^{* * *} \\
(6.124)\end{array}$ & $\begin{array}{c}-2.401 \\
(3.402)\end{array}$ & $\begin{array}{l}-7.313 \\
(14.345)\end{array}$ & $\begin{array}{c}17.757 \\
(27.199)\end{array}$ & $\begin{array}{c}35.019^{* *} \\
(15.674)\end{array}$ \\
\hline Years education & $\begin{array}{c}-3.212^{* * *} \\
(0.447)\end{array}$ & $\begin{array}{l}6.991^{* * *} \\
(0.852)\end{array}$ & $\begin{array}{c}-1.470^{* * *} \\
(0.473)\end{array}$ & $\begin{array}{r}-1.140 \\
(2.407)\end{array}$ & $\begin{array}{r}-2.964 \\
(4.563)\end{array}$ & $\begin{array}{c}0.262 \\
(2.630)\end{array}$ \\
\hline Earnings share & $\begin{array}{c}-94.403^{* * *} \\
(7.114)\end{array}$ & $\begin{array}{c}-251.751^{* * *} \\
(13.539)\end{array}$ & $\begin{array}{c}-73.328^{* * *} \\
(7.521)\end{array}$ & $\begin{array}{c}-82.196^{* * *} \\
(27.792)\end{array}$ & $\begin{array}{c}-226.910^{* * *} \\
(52.698)\end{array}$ & $\begin{array}{r}-48.719 \\
(30.368)\end{array}$ \\
\hline Child under 6 years & $\begin{array}{c}7.411^{* *} \\
(2.904)\end{array}$ & $\begin{array}{c}160.615^{* * *} \\
(5.527)\end{array}$ & $\begin{array}{c}-34.105^{* * *} \\
(3.070)\end{array}$ & $\begin{array}{l}-3.008 \\
(13.041)\end{array}$ & $\begin{array}{l}218.510^{* * *} \\
(24.728)\end{array}$ & $\begin{array}{c}-36.179^{* *} \\
(14.250)\end{array}$ \\
\hline Lesbian* children under 6 years & $\begin{array}{l}-2.896 \\
(39.513)\end{array}$ & $\begin{array}{r}-104.173 \\
(75.205)\end{array}$ & $\begin{array}{l}-1.037 \\
(41.776)\end{array}$ & $\begin{array}{l}-5.566 \\
(43.064)\end{array}$ & $\begin{array}{c}-84.922 \\
(81.655)\end{array}$ & $\begin{array}{c}29.954 \\
(47.055)\end{array}$ \\
\hline Year effects & Yes & Yes & Yes & Yes & Yes & Yes \\
\hline Observations & 14,397 & & & 679 & & \\
\hline$R^{2}$ & 0.0725 & 0.316 & 0.114 & 0.0946 & 0.302 & 0.152 \\
\hline$C h i^{2}$ & 21593.6 & 6637.5 & 30945.3 & 70.93 & 293.6 & 122.1 \\
\hline$p$ & 0.00 & 0.00 & 0.00 & 0.00 & 0.00 & 0.00 \\
\hline
\end{tabular}

Note: Authors' calculations from Seemingly Unrelated Regressions on American Time Use Survey data, 2003-2013. Specifications also include controls for weekly earnings, weekly earnings of spouse/partner, as well as indicators for time use on a holiday, time use during the summer, the presence of a non-own child, home ownership, residence in a state with same-sex marriage legal. ${ }^{*}$ Significant at $10 \%{ }^{* *}$ Significant at $5 \%{ }^{* * *}$ Significant at $1 \%$. 


\section{NOTES}

1 Household labor refers to unpaid household maintenance activities such as cooking, cleaning and yard work; care labor refers to unpaid work related to the care of children and adults in the household, and leisure refers to time spent resting and relaxing (sleep is not included in leisure). For a larger discussion of the distinction between unpaid household work and leisure, see Folbre (2008).

2 Countries included in this non-exhaustive list of literature include US, India, Argentina, South Africa, Tanzania, Republic of Korea, Nicaragua, and OECD countries considered together.

3 Due to the paucity of data regarding gay men and lesbians, we use the terms 'gay' and 'lesbian' to refer to individuals who researchers identify as behaviorally gay using sexual behavior and cohabitation status. For a comprehensive review of the literature, see Klawitter (2015).

4 For brevity, we do not include a full accounting of the literature investigating alternative sources of the earnings effects of sexual orientation. For summaries, see Berg and Lien (2002), Sabia (2015), Klawitter (2015), and Martell (2013).

5 While other social scientists have investigated the dynamics of same-sex households [see Dalton and Bielby (2000) and Ryan and Berkowitz (2009) as examples], the representativeness of this work may be limited as it utilizes qualitative research and non-random samples. We focus here on conclusions from more representative research.

6 Allen (2015) works with Canadian time-use data from 2006 and attempts to estimate the value of household production in same-sex versus different-sex households. While the primary focus of his paper is not specialization, he does find differences in the household division of labor in same-sex and different-sex households. However, he does not find a statistical difference in the value of household commodities produced in these two different types of households. Gay and lesbian households are more likely to purchase household services, which decreases the burden of their household duties relative to heterosexual couples.

7 The focus of Schneebaum's work is on the dynamics within same-sex households rather than comparison between same-sex and heterosexual households. Her analysis does not directly compare time use of gay men to heterosexual men and lesbians to heterosexual women after controlling for other characteristics.

8 Schneebaum also finds that the amount of unpaid labor performed by gay men and lesbians is responsive to proxies related to bargaining power, which she claims is evidence of specialization occurring in same-sex households.

9 Oreffice (2011) applies the collective model from Chiapporri et al. (2002) to gay and lesbian households.

10 According to Becker's model, if a lesbian couple chooses to have one partner carry and give birth to a child the differences in market versus household specialization would arise due to differences in initial investment in human capital specific to household and care work.

11 For example, high earning women are predicted to spend less time in unpaid work than her male partner in non-cooperative household bargaining models. However, given the persistence of the gender wage gap and social institutions that reinforce lower bargaining power among women in heterosexual relationships, existing economic models do not predict this outcome on average or at the margin.

12 The assumptions in economic models of the household differ with regard to whether household members maximize a single household utility function, i.e. in Becker's model, or maximize individual utility functions, i.e. a collective model or bargaining model.

13 Interdisciplinary research suggests that members of lesbian households endeavor to organize household duties such that household members complete an equal distribution of housework [Peplau and Fingerhut (2004)].

14 For example, Carter and Katz (1997) incorporate a parameter for "degree of patriarchy" in their model of household behavior.

15 See Frazis and Stewart (2007) and Frazis and Stewart (2012) for more detail on the ATUS and appropriate use of time-use data in general.

16 In specifications not reported here, we note that our main pattern of results is qualitatively similar, though somewhat less precise, to the results we discuss below when we relax this age restriction. An 
additional concern is that our time-use patterns may be imprecise due to varying likelihoods that both members of a household will be employed by sexual orientation. However, our time-use estimates for both men and women are robust to alternative specifications in which we limit our sample to those households in which only both partners are employed.

17 The ATUS survey lists roommate as a separate category. We do not include roommates in our sample.

18 The age difference in our data is inconsistent with some of the existing demographic research. For instance, Gates (2013) finds that gay men in the ACS are younger than heterosexual men. The age difference in our sample is driven by our focus on individuals aged 25 years to 54 years. When we exclude older individuals, who are predominately heterosexual, we find that gay men are younger than heterosexual men in part because they form partnerships later in life.

19 The meaningful difference in the propensity of lesbians to live in states with legalized same-sex marriage suggests (the collection of the ATUS data used here preceded the nation-wide legalization of same-sex marriage in the US), to the extent that the size of the lesbian population does not lead to legal changes, that lesbians may choose to migrate to states with more favorable legal institutions. These legal institutions may be particularly important for lesbian households who are disproportionately affected by the gender wage gap in addition to any disadvantage associated with their sexual orientation. As such, researchers investigating the impact of same-sex marriage laws may be concerned that such migration may pose a bias in the evaluation of the impact of same-sex marriage on economic outcomes. However, since we are interested in average time use patterns in same-sex households and not the impact of marriage on time use, such a pattern will not bias our results. The pattern does not bias our results, because we adequately control for the distribution of lesbian households across states with same-sex marriage as we discuss in the next section.

20 We use the time use categories from the BLS. Household labor (called "Household activities" in the ATUS lexicon) includes housework, food preparation and clean up, lawn and garden care, household management, interior maintenance, repair and decoration, exterior maintenance repair and decoration, animals and pets, vehicles, appliance tools, and toys, travel related to household activities and household activities not elsewhere classified. Leisure includes socializing and communicating, attending or hosting social events, relaxing and leisure, arts and entertainment (other than sports), and waiting associating with socializing. Note that sports, exercise and recreation are in a separate category and not counted in leisure. Care labor (called "Caring for helping household members" in the ATUS lexicon) includes caring for and helping household children (both as a primary and secondary activity), activities related to household children's education, activities related to household children's health, caring for household adults, helping household adults and caring for or helping household members not elsewhere classified.

21 For examples and discussion, see Kimmel and Connelly (2007) and Raley et al. (2012) who also include secondary childcare in measures of total care labor.

22 As is standard practice, Kimmel and Connelly (2007) and Raley et al. (2012) also include secondary childcare in their measures of total care time.

23 Schneebaum (2013) considers the impact of children on time use in gay and lesbian households; however, her specification differs from ours in that she analyzes individuals with same-sex partners and individuals with different-sex partners separately making a comparison of overall time use, and the impact of children, difficult.

24 Whether reports of zero time use in the ATUS represent classical measurement error or censoring generally depends on the time frame of reference in estimation [Stewart (2013)]. As we are interested in representative longer term averages, zero minutes reported in household labor reflects measurement error as all household members perform some household labor. Reporting zero minutes on a particular day represents a time-use report that does not correctly reflect an average. The difference between average household labor performed and the time-use report is a classical measurement error, which is why we estimate time use via Seemingly Unrelated Regressions (SUR). Since we use the same covariates in all time-use specifications, our empirical specification simplifies to a standard Ordinary Least Squares (OLS) (Greene, 2002).

25 Similar to other federal and national surveys in the US, the probability weights for the ATUS weight racial minorities more heavily, and white respondents less heavily, to make population estimates 
nationally representative. As members of same-sex households are more likely to be white, such an adjustment will inflate estimated standard errors for gay men and lesbians thereby exacerbating the difficulty that small samples pose for empirical research of same-sex households. Such an inflation of standard errors will only compound the inflation of standard errors that may occur if researchers use survey weights in the absence of endogenous sampling. Endogenous sampling is a concern in time-use research if survey non-response remains correlated with time use after controlling for relevant factors [Solon et al. (2015)]. Existing research finds that survey non-response is not correlated with time use. Respondents who appear to be busy and have more time pressures are no less likely to respond to the ATUS than those who are not [Abraham et al. (2006)]. Since there is no evidence of endogenous sampling and we utilize a comprehensive set of controls, we do not use probability weights in our estimation.

26 Indicators for laws making same-sex marriage legal are an imperfect control for tolerance of homosexuality. Tolerance of homosexuality may not have been a leading cause of legalization of marriage in states where legalization of same-sex marriage was a judicial decision. However, these states tend to have higher levels of tolerance of homosexuality in part due to the public debate that surrounds the implementation of policies affecting Lesbian Gay or Bisexual (LGB) people regardless of the channel through which implementation occurs [Haider-Markel and Meier (1996)]. These states are also more likely to have laws making sexual orientation based discrimination illegal, which have also been accompanied with rising levels of tolerance [Martell (2013b)]. Given the collinearity with regional controls and that lesbians exhibit a much higher propensity to live in states where samesex marriage is legal, we believe the legalization of same-sex marriage is a more accurate control for regional and attitudinal variations that will affect time use. Nevertheless, in specifications not presented here, we find that our results are very similar when we replace the same-sex marriage law control with regional controls.

27 This is consistent with the approaches of the many of researchers comparing same-sex to different-sex households [Antecol et al. (2008); Giddings et al. (2014); Jepsen and Jepsen (2015)].

28 When only considering care labor done as a primary activity, i.e. excluding secondary childcare, gay men still do on average less than heterosexual married men, but the difference is much smaller, 18 minutes daily, and the level of significance drops to the $10 \%$ level. These results are not shown here but available upon request.

29 The positive significant coefficient found for the impact of education on care labor is consistent with findings from Raley et al. (2012) who investigate time fathers and mothers spend on childcare with ATUS data. The sign and statistical significance of the education variable for married men holds in all specifications other than regression for men without children.

30 An exception would be gay men and lesbians who have children from previous heterosexual relationships.

31 While the number of gay men and lesbians with children under 6 years in the data is small, we nevertheless include the interaction term for exploratory purposes. The small sample renders it unlikely that the coefficient estimate of the interaction term will be significant.

32 Results available upon request.

33 The estimated differences for the most part are also not economically meaningful.

34 The significant positive coefficient on the dummy for being white in the specifications predicting time spent on household labor (in both the married and unmarried samples) is consistent with findings from Kimmel and Connelly (2007). The positive coefficient on education for care time for married women with children is consistent with Raley et al. (2012).

35 This is consistent with findings by Allen (2015).

\section{REFERENCES}

Abraham, Katharine G., Aaron Maitland and Suzanne Bianchi (2006) Nonresponse in the american time use survey: Who is missing from the data and how much does it matter? Public Opinion Quarterly 70(5), 676-703. 
Agarwal, Bina (1997) "Bargaining"and gender relations: Within and beyond the household. Feminist Economics 3(1), 1-51.

Ahmed, Ali M., Lina Andersson and Mats Hammarstedt (2011) Inter- and intra-household earnings differentials among homosexual and heterosexual couples. British Journal of Industrial Relations 49(2), 248-278.

Ahmed, Ali M., Lina Andersson and Mats Hammarstedt (2013) Sexual orientation and full-time monthly earnings, by public and private sector: Evidence from Swedish register data. Review of Economics of the Household 11(1), 83-108.

Ahmed, Ali M. and Mats Hammarstedt (2010) Sexual orientation and earnings: A register data-based approach to identify homosexuals. Journal of Population Economics 23(3), 835-849.

Allen, Douglas W. (2015) Household production and sexual orientation. Economic Inquiry 53(1), 406-418.

Antecol, Heather, Anneke Jong and Michael Steinberger (2008) The sexual orientation wage gap: The role of occupational sorting, human capital and discrimination. Industrial and Labor Relations Review 61(4), 518-543.

Antecol, Heather and Michael D. Steinberger (2013) Labor supply differences between married heterosexual women and partnered lesbians: A semi-parametric decomposition approach. Economic Inquiry 51(1), 783-805.

Arabsheibani, G. Reza, Alan Marin, and Jonathan Wadsworth (2004) In the pink: Homosexualheterosexual wage differentials in the U.K. International Journal of Manpower 25(3), 343-354.

Badgett, M. V. Lee (1995) The wage effects of sexual orientation discrimination. Industrial and Labor Relations Review 54(3), 726-739.

Baumle, Amanda K. and Dudley L. Poston (2011) The economic cost of homosexuality: Multilevel analyses. Social Forces 89(3), 1005-1031.

Becker, G. S. (1981) A Treatise on the Family. Cambridge: Cambridge, MA: Harvard University Press.

Berg, Nathan and Donald Lien (2002) Measuring the effect of sexual orientation on income: Evidence of discrimination? Contemporary Economic Policy 20(4), 394-414.

Biblarz, Timothy J. and Evren Savci (2010) Lesbian, gay, bisexual, and transgender families. Journal of Marriage and Family 72(3), 480-497.

Black, Dan, Seth Sanders and Lowell Taylor (2007) The economics of lesbian and gay families. Journal of Economic Perspectives 21(2), 53-70.

Blau, Francine and Lawrence Kahn (2005) Changes in the Labor Supply of Behavior of Married Women: 1980-2000. NBER working paper 11230, http://www.nber.org/papers/w11230. National Bureau of Economic Research.

Bredtman, Julia (2014) The intra-household division of labor: An empirical analysis of spousal influences on individual time allocation. LABOUR: Review of Labour Economics and Industrial Relations 28(1), 1-39.

Budlender, Debbie (2000) The political economy of women's budgets in the south. World Development 28(7), 1365-1378.

Carpenter, Christopher S. (2007) Revisiting the income penalty for behaviorally gay men: Evidence from NHANES III. Labour Economics 14, 25-34.

Carter, Michael and Elizabeth Katz (1997) Separate spheres and the conjugal contract: Understanding the impact of gender-biased development. In Intrahousehold Resource Allocation in Developing Countries: Methods, Models and Policies, pp. 95-111. Baltimore: The Johns Hopkins University Press.

Chiappori, Pierre-Andre (1992) Collective labor supply and welfare. Journal of Political Economy 100(3), 437-467.

Chiappori, Pierre-André, Bernard Fortin and Guy Lacroix (2002) Marriage market, divorce legislation, and household labor supply. Journal of political Economy 110(1), 37-72.

Clain, Suzanne Heller and Karen Leppel (2001) An investigation into sexual orientation discrimination as an explanation for wage differences. Applied Economics 33, 37-47. 
Clarke, Geoff and Purvi Sevak (2013) The disappearing gay income penalty. Economics Letters 121, 542-545.

Cushing-Daniels, Brendan and Tsz-Ying Yeung (2009) Wage penalties and sexual orientation: An update using the General Social Survey. Contemporary Economic Policy 27(2), 164-175.

Dalton, Susan E. and Denise D. Bielby (2000) "That's our kind of constellation" lesbian mothers negotiate institutionalized understandings of gender within the family. Gender \& Society 14(1), $36-61$.

Daneshvary, Nasser, C. Jeffrey Waddoups and Bradley S. Wimmer (2008) Educational attainment and the lesbian wage premium. Journal of Labor Research 29, 365-379.

Daneshvary, Nasser, C. Jeffrey Waddoups and Bradley S. Wimmer (2009) Previous marriage and the lesbian wage premium. Industrial Relations 48(3), 432-453.

Doss, Cheryl R. (1996) Testing among models of intrahousehold resource allocation. World Development 24(10), 1597-1609.

Folbre, N. (2008) Valuing Children: Rethinking the Economics of the Family. Cambridge, MA: Harvard University Press.

Frazis, H. and J. Stewart (2007) Where does the time go? Concepts and measurement in the american time use survey. In Hard-to-Measure Goods and Services: Essays in Honor of Zvi Griliches, pp. 73-97. Chicago: University of Chicago Press.

Frazis, Harley and Jay Stewart (2012) How to think about time-use data: What inferences can we make about long-and short-run time use from time diaries? Annals of Economics and Statistics/ANNALES D'ÉCONOMIE ET DE STATISTIQUE 105-106, 231-245.

Gates, Gary J. (2013) Same-sex and different-sex couples in the American community survey: 20052011. UCLA: The Williams Institute. Retrieved from: http://escholarship.org/uc/item/8dk71277

Gates, Gary J. and Abigail M. Cooke (2011) United states census snapshot: 2010. UCLA: The Williams Institute Retrieved from: https://escholarship.org/uc/item/4j23r1rx.

Giddings, Lisa, John M. Nunley, Alyssa Schneebaum, and Joachim Zietz (2014) Birth cohort and the specialization gay between same-sex and different-sex couples. Demography 51, 509-534.

Greene, W. (2002) Econometric Analysis, 5th ed. New Jersey, NJ: Prentice Hall.

Haider-Markel, Donald P. and Kenneth J. Meier (1996) The politics of gay and lesbian rights: Expanding the scope of the conflict. The Journal of Politics 58(2), 332-349.

Hener, Timo (2015) Do couples bargain over fertility? Annals of Economics and Statistics/Annales d'Économie et de Statistique 117-118, 211-231.

Hersch, Joni and Leslie Stratton (1997) Housework, fixed effects, and wages of married workers. Journal of Human Resources 32(2), 285-307.

Jepsen, Christopher and Lisa K. Jepsen (2015) Labor-market specialization within same-sex and different-sex couples. Industrial Relations 54(1), 109-130.

Jepsen, Lisa K. (2007) Comparing the earnings of cohabiting lesbians, cohabiting heterosexual women, and married women: Evidence from the 2000 Census. Industrial Relations 46(4), 699-727.

Kimmel, Jean and Rachel Connelly (2007) Mothers' time choices: Caregiving, leisure, home production and paid work. Journal of Human Resources 42(3), 643-681.

Klawitter, Marieka (2011) Multilevel analysis of the effects of antidiscrimination policies on earnings by sexual orientation. Journal of Policy Analysis and Management 30(2), 334-358.

Klawitter, Marieka (2015) Meta-analysis of the effects of sexual orientation on earnings. Industrial Relations 54(1), 4-32.

Klawitter, Marieka and Victor Flatt (1998) The effects of state and local anti-discrimination policies on earnings for gays and lesbians. Journal of Policy Analysis and Management 4, 658-686.

Lundberg, Shelly and Robert A Pollak (1994) Noncooperative bargaining models of marriage. The American Economic Review 84(2), 132-137.

Lundberg, Shelly and Robert A Pollak (1996) Bargaining and distribution in marriage. The Journal of Economic Perspectives 10(3), 139-158.

Manser, Marilyn and Murray Brown (1980) Marriage and household decision-making: A bargaining analysis. International Economic Review 21(1), 31-44. 
Martell, Michael E. (2013a) Differences do not matter: Exploring the wage gap for same-sex behaving men. Eastern Economic Journal 39(1), 45-71.

Martell, Michael E. (2013b) Do ENDAs end discrimination for behaviorally gay men? Journal of Labor Research 34(2), 147-169.

Martell, Michael E. (2014) How ENDAs extend the workweek: Legal protection and the labor supply of behaviorally gay men. Contemporary Economic Policy 32(3), 560-577.

Masterson, Thomas (2012) An empirical analysis of gender bias in education spending in paraguay. World Development 40(3), 583-593.

McElroy, Marjorie B. and Mary Jean Horney (1981) Nash-bargained household decisions: Toward a generalization of the theory of demand. International Economic Review 22(2), 333-349.

Movement Advancement Project (2014) Snapshot: LGBT legal equality by state. Date Accessed: November 10, 2014.

Oerton, Sarah (1998) Reclaiming the 'housewife'? Lesbians and household work. Journal of Lesbian Studies 2(4), 69-83.

Orrefice, Sonia (2011) Sexual orientation and household decision making: Same-sex couples' balance of power and labor supply choices. Labour Economics 18(2), 145-158.

Padavic, Irene and Jonniann Butterfield (2011) Mothers, fathers, and "mathers" negotiating a lesbian co-parental identity. Gender \& Society 25(2), 176-196.

Peplau, Letitia A. and Adam Fingerhut (2004) The paradox of the lesbian worker. Journal of Social Issues 60(4), 719-735.

Plug, E. and P. Berkhout (2008) Sexual Orientation, Disclosure and Earnings. IZA discussion paper 3290. Institute for the Study of Labor.

Raley, Sara, Suzanne M. Bianchi and Wendy Wang (2012) When do fathers care? mothers' economic contribution and fathers' involvement in child care. American Journal of Sociology 117(5), 14221459 .

Ruggles, Steven, Katie Genadek, Ronal Goeken, Josiah Grover, and Matthew Sobek (2015) Integrated Public Use Microdata Series: Version 6.0. Minneapolis: University of Minnesota.

Ruppanner, Leah and David J. Maume (2016) The state of domestic affairs: Housework, gender and state-level institutional logics. Social Science Research.

Ryan, Maura and Dana Berkowitz (2009) Constructing gay and lesbian parent families "beyond the closet". Qualitative sociology 32(2), 153-172.

Sabia, Joseph J. (2015) Fluidity in sexual identity, unmeasured heterogeneity, and the earnings effects of sexual orientation. Industrial Relations 54(1), 33-58.

Sayer, Liane C. (2005) Gender, time and inequality: Trends in women's and men's paid work, unpaid work and free time. Social Forces 84(1), 258-303.

Schneebaum, A. (2013) The Economics of Same-Sex Couple Households: Essays on Work, Wages, and Poverty. Ph.D. thesis, University of Massachusetts at Amherst.

Sen, A. K. (1990) Gender and cooperative conflict. In I. Tinker (ed.), Persistent Inequalities, pp. 123-149. New York: Oxford University Press.

Solon, Gary, Steven J. Haider and Jeffrey M. Wooldridge (2015) What are we weighting for? The Journal of Human Resources 50(2), 301-316.

Stewart, Jay (2013) Tobit or not tobit? Journal of Economic and Social Measurement 38(3), 263-290.

Stratton, Leslie S. (2015) The determinants of housework time. IZA World of Labor 133, 1-10.

US Bureau of Labor Statistics (2013) American time use survey activity lexicon. Available at http://www.bls.gov/tus/lexiconnoex0312.pdf Date Accessed: December 10, 2014. 